Chapter 23

\title{
Exposure and Hazard Identification of Sulphonamides in the Terrestrial Environment
}

\author{
Anna Białk-Bielińska, Joanna Maszkowska, \\ Alan Puckowski and Piotr Stepnowski \\ Additional information is available at the end of the chapter \\ http://dx.doi.org/10.5772/57265
}

\section{Introduction}

For ten years now, interest has been increasing in research focused on pharmaceutical residues in the environment. Special attention has been given to the residues of antimicrobials, since it has been demonstrated, that due to the formation of the dangerous phenomenon of bacterial resistance, these substances could pose a real threat not just to ecosystems, but also to human health. Most antimicrobial agents are used in large quantities for different purposes in veterinary medicine.

Various antibiotics are commonly used in this field, but we shall concentrate on sulphonamides (SAs). The physicochemical properties and chemical structures of selected SAs are presented in Table 1.

Having been used for more than fifty years, SAs are among the oldest groups of veterinary chemotherapeutic substances. They are inexpensive and offer a broad spectrum of activity for the prevention and treatment of bacterial infections. After tetracyclines, they are the most commonly consumed veterinary antibiotics in the European Union $[1,10]$. However, as animals do not completely metabolize these compounds, a large fraction of them is being excreted unchanged in faeces and urine. Therefore, both the unmetabolized drugs and their metabolites are discharged to the environment, mainly to the soil component, either directly by grazing animals or indirectly during the application of manure [11]. Once in the soil, they and their transformation products are distributed among its different compartments and can be transported to the surface and ground waters. The physicochemical properties of these compounds, the applied dosage and the nature of the environmental compartment where they are released and further interact, comply the whole process. 


\section{Substance [CAS]}

Abbreviation

Sulphachloropyridazine
[80-32-0]

Sulphadiazine

[68-35-9]<smiles>Nc1ccc(S(=O)(=O)Nc2ncccn2)cc1</smiles>

$M=250.3 \mathrm{~g} \mathrm{~mol}^{-1}$

$\mathrm{pK}_{\mathrm{a} 2}=1.98$

$\mathrm{pK}_{\mathrm{a} 3}=6.01$

SDZ

O

$\log P=-0.09$

Sulphadimethoxine

[122-11-2]

SDM

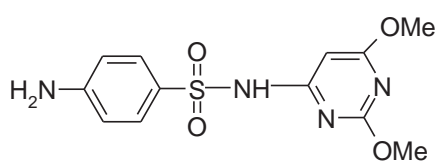

$M=310.3 \mathrm{~g} \mathrm{~mol}^{-1}$

$\mathrm{pK}_{\mathrm{a} 2}=2.5$

$\mathrm{pK}_{\mathrm{a} 3}=6.0$

$\log P=1.63$

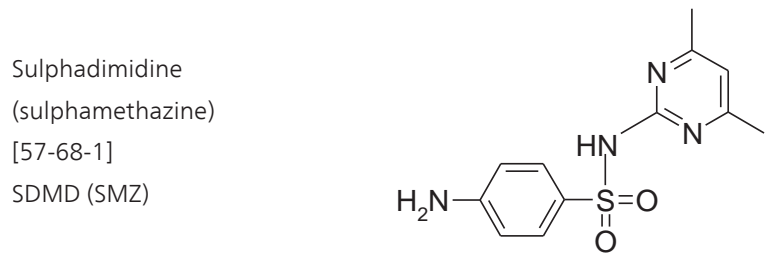

$$
\begin{gathered}
\mathrm{M}=278.3 \mathrm{~g} \mathrm{~mol}^{-1} \\
\mathrm{pK}_{\mathrm{a} 2}=2.46 \\
\mathrm{pK}_{\mathrm{a} 3}=7.45 \\
\log \mathrm{P}=0.27
\end{gathered}
$$

Sulphaguanidine

[57-67-0]

$\mathrm{SGD}$
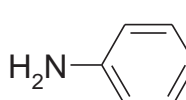<smiles>CCN[SiH2][Os]</smiles>

$\mathrm{O}$<smiles>CC(=N)N</smiles>

$M=214.2 \mathrm{~g} \mathrm{~mol}^{-1}$

$\mathrm{pK}_{\mathrm{a} 2}=2.8$

$\mathrm{pK}_{\mathrm{a} 3}=12.0$

$\log P=-1.22$

$\mathrm{M}=264.3 \mathrm{~g} \mathrm{~mol}^{-1}$

$\mathrm{pK}_{\mathrm{a} 2}=2.16$

$\mathrm{pK}_{\mathrm{a} 3}=6.80$

$\log P=0.11$
Sulphamethoxazole

[723-46-6]

SMX
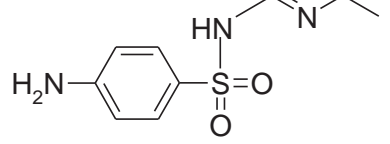

$M=253.3 \mathrm{~g} \mathrm{~mol}-1$

$\mathrm{pK}_{\mathrm{a} 2}=1.81$

$\mathrm{pK}_{\mathrm{a} 3}=5.46$

$\log P=0.89$ 


\section{Substance [CAS]}

Abbreviation

Sulphamonomethoxine

[1220-83-3]

SMM

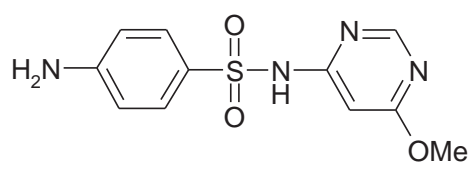

$$
\begin{gathered}
\mathrm{M}=280.3 \mathrm{~g} \mathrm{~mol}^{-1} \\
\mathrm{pK}_{\mathrm{a} 2}=1.73 \\
\mathrm{pK}_{\mathrm{a} 3}=6.22 \\
\log \mathrm{P}=-0.04
\end{gathered}
$$

Sulphapyridine
S144-83-2]

Sulphathiazole
Sulphisoxazole
[127-69-5]
SSX

Table 1. The structures and physicochemical properties of the sulphonamides discussed in this chapter (according to [1-9])

SAs are fairly water-soluble, polar compounds, however quite persistent - resistant to biodegradation [10,12-13] and hydrolysis [3]. This goes a long way to explaining why they have been regularly detected in both aquatic and terrestrial environments in the last ten years [1,10-11]. Although SA concentrations in environmental samples are relatively low (at the ppb or ppt level), they are continuously being released, so ultimately they may pose an elevated risk. SAs are designed to specifically target the biosynthetic pathway of folate (an essential molecule required by all living organisms) by competitively inhibiting the conversion of $p$-aminobenzoic acid (pABA); hence, they not only target bacteria but can also elicit hitherto unknown effects in environmentally relevant, non-target organisms like invertebrates and plants [14-16]. As they belong to different trophic levels, these taxonomic groups may be exposed to SAs to various extents.

So far only a small number of studies concerning the presence and effects of SAs in the soil environment have been carried out. Hence, there are a number of very pertinent questions that 
need to be addressed, for example: (i) What is the fate of these compounds in the terrestrial environment? (ii) What are the effects of their presence in the soil environment? (iii) Do they pose a risk to different soil organisms and also to human health?

For these reasons, the aim of this chapter is to review and summarize existing knowledge of the fate and effects of SA residues in the terrestrial environment.

Conventionally, the environmental fate of antimicrobials in the soil ecosystem is assessed with respect to their persistence and sorption onto soil. In the case of SAs, as they are very stable, only photodegradation process could have recognizable influence on their elimination from the environment $[1,10]$. However this process in the soil ecosystem is of lesser importance. Therefore, sorption processes influence the environmental behaviour of SAs to the greatest extent, so it is these that we shall be discussing in detail.

Although a few review papers have been published summarizing the available ecotoxicity data of pharmaceuticals, including some SAs [14-15,17-18], they focus on aquatic organisms rather than soil. In this chapter, therefore, we shall discuss the available data on SA toxicity towards different soil organisms on various trophic levels like bacteria, invertebrates and plants. These results will be discussed with respect to the existing requirements for the environmental risk assessment of veterinary pharmaceuticals (VICH, 2000 [19]; VICH, 2004 [20]; EMEA, 2007 [21]; EMEA, 2008a [22]; EMEA, 2008b [23]). In addition, we shall identify some areas where future work is warranted as well as the needs for further investigations.

\section{Fate of SAs in the terrestrial environment}

\subsection{Basic concept of sorption modelling studies}

Sorption is defined as a phenomenon during which chemicals become associated with solid phases. Immensely important, this process affects the fate of chemicals in the environment [24-25]. Adsorption/desorption experiments are useful for generating essential information on the mobility of various contaminants and their distribution in the soil, water and air. Assessing the distribution of a chemical between the soil and aqueous phases is not a straightforward process, however. It depends on various factors, such as the chemical nature of the substance and the characteristics of the soil (e.g. $\mathrm{pH}$, organic matter $(\mathrm{OM})$ content, clay fraction content). Furthermore, climatic factors such as rainfall, temperature, sunlight intensity and wind, which can affect the strength of sorption, also have to be taken into consideration. Thus, the numerous phenomena and mechanisms involved in the adsorption of a chemical by soil cannot be completely defined by simple laboratory models. Nevertheless, such investigations can provide valuable information on the environmental relevance of the adsorption of chemicals [26].

Laboratory sorption experiments can be carried out under static (batch) and dynamic (column) conditions. Static tests are commonly used when the aim of the study is to calculate the distribution coefficient (Eq. 1), in equilibrium time, which is specific to every chemical. Column tests, on the other hand, enable time-dependent monitoring of contaminant 
leaching from soil and waste materials; in addition, the flow-through pattern of such tests resembles actual environmental conditions. Therefore, the release of a contaminant depending on local equilibrium time and advection conditions can be evaluated based on column testing systems [27].

Both column and batch tests can be used to assess the possible leaching/release potential of contaminated materials on the soil - ground water pathway [28-30]. The release potential of water-soluble contaminants can be assessed as an expression of the source term, which gives an indication of their bioavailability. In this case a batch test provides a snapshot of a particular liquid-to-solid ratio. This type of test focuses on constituent solubility and release over a range of conditions by varying a single parameter (e.g. final extract $\mathrm{pH}$, liquid-to-solid (LS) ratio) [27].

The common approach for modelling sorption results involves using only the initial linear part of the isotherm, plotted as $\mathrm{c}_{\mathrm{w}}$ and $\mathrm{c}_{\mathrm{s}}$ :

$$
c_{s}=K_{d} \cdot c_{w}
$$

where: $K_{d}$ is the partition coefficient; $c_{s}$ is the content of test substance adsorbed on the soil at adsorption equilibrium $\left(\mathrm{mg} \mathrm{kg}^{-1}\right) ; c_{w}$ is the mass concentration of test substance in the aqueous phase at adsorption equilibrium $\left(\mathrm{mg} \mathrm{L}^{-1}\right)$.

The sorption isotherm can be also mathematically described by the Freundlich or Langmuir model.

The Langmuir equation is written as:

$$
c_{s}=\frac{c_{\max } \cdot K_{L} \cdot c_{w}}{1+K_{L} \cdot c_{w}}
$$

where: $c_{s}$ is the content of test substance adsorbed on the soil at adsorption equilibrium (mg $\left.\mathrm{kg}^{-1}\right) ; c_{w}$ is the mass concentration of test substance in the aqueous phase at adsorption equilibrium $\left(\mathrm{mg} \mathrm{L}^{-1}\right) ; c_{\max }$ is the maximum sorption capacity of the sorbent; $K_{L}$ is the Langmuir constant.

The linear form of this equation is:

$$
\frac{1}{c_{s}}=\frac{1}{K_{L} c_{\max } c_{w}}+\frac{1}{c_{\max }}
$$

In the Langmuir model the mass of solute sorbed per unit mass of sorbent $\left(c_{s}\right)$ increases linearly as the solute concentration increases. The model is based on three main assumptions:

- the sorption energy is the same for all sites and is independent of the degree of surface coverage; 
- sorption occurs only at localized sites, with no interaction between adjoining sorbed molecules;

- the sorption maximum $\left(c_{\max }\right)$ represents a monolayer coverage.

Based on these findings, it is justified that the Langmuir isotherms are observed only very rarely in case of sorption of when organic compounds are sorbed in such a complex and heterogeneous sorbent as soils [31].

The Freundlich model takes the following form:

$$
c_{s}=K_{F} \cdot c_{w}^{1 / n}
$$

where: $c_{s}$ is the content of test substance adsorbed on the soil at adsorption equilibrium (mg $\left.\mathrm{kg}^{-1}\right) ; c_{w}$ is the mass concentration of test substance in the aqueous phase at adsorption equilibrium $\left(\mathrm{mg} \mathrm{L}^{-1}\right) ; K_{F}$ is the Freundlich adsorption coefficient; $n$ is the regression constant

Based on the value of $1 / n$, which describes the relative magnitude and diversity of energies associated with sorption, the mechanism of this process can be defined more accurately [31-36]. If $1 / n=1$, adsorption is linear, which indicates the occurrence of homogeneous energy sites on the sorbent. This type of adsorption is generally typical at very low solute concentrations with many sites on the sorbent still available for possible interaction with the adsorbate. A value of $1 / n>1$ indicates a concave, upward-curving isotherm, which is sometimes referred to as a solvent-affinity type isotherm (S-type), where the sorption energy increases with increasing surface concentration. However, phenomena unrelated to the sorption of the analyte to the sorbate surface, such as strong adsorption of the solvent, strong intermolecular attraction within the adsorbent layers, penetration of the solute in the adsorbent, and the monofunctional nature of the adsorbate, can also affect the shape of the isotherm [31]. When $1 / n<1$, the isotherm is of the convex, downward-curving Langmuir-type (L-type), where the marginal sorption energy decreases with increasing surface concentration. This may occur when the competition of solvent for sites is minimal or the absorbate is a planar molecule [36].

In order to calculate the Freundlich factors as $1 / n$ or $K_{F}$, Eq. 4 can be linearized by a logarithmic transformation:

$$
\log c_{s}=1 / n \log c_{w}+\log K_{F}
$$

It has been shown that the sorption of pharmaceutical compounds (PCs) to soils is influenced by solution chemistry and the type of mineral and organic sorbents $[24,25,37]$. Pharmaceuticals can exist as either neutral or charged species (e.g. cations, anions, zwitterions) [24], depending on the $\mathrm{pH}$. Various adsorptive forces may therefore be acting. Whereas neutral molecules partition to solid matrices via relatively weak van der Waals and electron donor-acceptor interactions, charged species can interact via stronger electrostatic mechanisms, such as cation exchange, cation-bridging and complexation. The acid-base equilibrium of sulphonamides 
resulting from either the loss or the gain of a proton is similar for all sulphonamides apart from sulphaguanidine (see Białk-Bielińska et al. [3]). The basic properties are due to the aniline group present in all SAs and specific to each SA heterocyclic base. SAs can thus be described by three dissociation constants. Nevertheless, since the presence of the protonated form of the heterocyclic functional group is extremely unlikely, only two of the possible ionized functional groups existing in the structure of SA molecules are taken into consideration - during sorption experiments [38-45]. Hence, $\mathrm{K}_{\mathrm{a} 2}$ is the dissociation constant for the equilibrium between the positively charged, protonated amino group of a SA and its electrically neutral conjugate base, whereas $\mathrm{K}_{\mathrm{a} 3}$ refers to the equilibrium involving the loss of the SA proton to yield its negatively charged conjugate (Figure 1) [7].

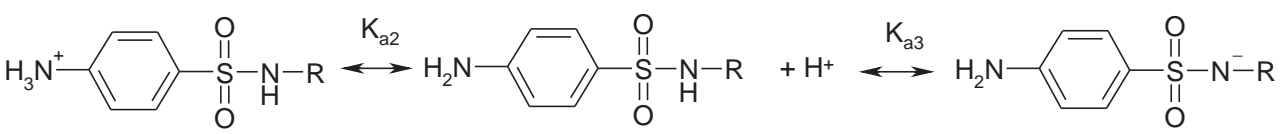

Figure 1. Dissociation equilibrium of sulphonamides [7]

Assessing the sorption of veterinary pharmaceuticals in soils is extremely important for estimating the risk of the large-scale usage of veterinary medicines to human health and environmental matrices, because this affects the fate and transport of chemicals in ground water.

\subsection{Sorption potential of SAs to soils}

Although SA sorption is quite a common topic of investigation, authors generally focus on just a few SAs, so that knowledge of the sorption behaviour of some of them (e.g. sulphaguanidine, sulphisoxazole) is still limited. So far, only a few review papers have been published describing the sorption of SAs to soils [16,46-49]. However, they cover a wide range of pharmaceuticals, so SAs are inadequately reviewed. Furthermore, since 2011 (when the last review on SA sorption was published), new data have been published, which are included in the present review. The available information on the sorption of the most commonly investigated compounds will therefore be discussed in depth.

The most widely investigated SA is sulphamethazine (SMZ). The level to which its undergoing sorption onto soils was investigated already more than thirty years ago by Langhammer [50]. That author calculated adsorption coefficients for four different soils, differing in $\mathrm{pH}$ and $\mathrm{OM}$ content. Based on the values of the distribution coefficients (from 1.0 to $3.1 \mathrm{~L} \mathrm{~kg}^{-1}$ ), this drug can be considered as a very mobile chemical. These results are in accordance with the investigations of other researchers, such as Thurman et al. [51] and Tolls et al. [52], who reported low sorption coefficients for SMZ $\left(0.6 \mathrm{~L} \mathrm{~kg}^{-1}\right.$ and $3.0 \mathrm{~L} \mathrm{~kg}^{-1}$ respectively) or Thiele-Bruhn et al. [53], who gave a $K_{d}$ value of $2.4 \mathrm{~L} \mathrm{~kg}^{-1}$ for humus-rich soil. This was also supported by Lertpaitoonpan et al. [54], who examined this SA in terms of the distribution in soils varying in OM content $\left(K_{d}\right.$ lies between 0.2 and $3.9 \mathrm{~L} \mathrm{~kg}^{-1}$ depending on the physicochemical parameters of soils). However, Fan et al. [55] reported a higher sorption potential of the polar metabolite 
of SMZ (N4-acetyl-SMZ) during a miscible-displacement experiment (column test). The $K_{d}$ values obtained by these authors range from 7.5 and to $206.2 \mathrm{~L} \mathrm{~kg}^{-1}$ and are much higher than previous data for the native compound. However, this may well be due to the polar functional group present in N4-acetyl-SMZ, which could enhance the association of this compound to the negatively charged soil surfaces via cation bridging or complexes. The high mobility of SMZ was also reported by Kurwadkar et al. [41], who observed a 50-90\% release of SMZ from a soil column system. The most recent studies presented by Leal et al. [56] underscore the concern regarding the possible occurrence of this compound in the environment. These authors investigated a number of different Brazilian soils, finding a tendency for SMZ to leach from soil matrices.

Much attention has also been given to calculating the sorption potential of sulphadiazine (SDZ). Just recently, Doretto et al. [45] reviewed the available literature data through Freundlich sorption coefficient $\left(K_{F}\right)$ for SDZ. On this basis they concluded that the potential of SDZ to interact with soil particles is relatively low and depends on the type of soil, thus on the physicochemical properties of the sorbent. In another work, these authors demonstrated the weak interaction of SDZ with binding sites on the soil surface $\left(K_{F}\right.$ values from 0.4 to $2.6 \mu \mathrm{g}^{1-1 /}$ $\left.{ }^{n}\left(\mathrm{~cm}^{3}\right)^{1-1 / n} \mathrm{~g}^{-1}\right)$. The column studies of Wehrhan et al. [57] showed that the amount of leached SDZ depends strongly on the duration of the process. The eluted mass fraction was considerably higher in long-pulse experiments (83 and 61\% respectively) than in short-pulse ones, during which only $18 \%$ was leached. Furthermore, these authors recorded the highest concentrations at the top of the column, with concentrations steadily decreasing towards the bottom. In the column with the short pulse application, solute concentrations were relatively uniformly distributed. Environmental conditions like rainfall can therefore affect the distribution of contaminants in soil.

It was also observed that SDZ exhibits, for example, a lower tendency to be retained in solid matrices than SMZ [53,56], with respective $K_{d}$ values for SDZ and SMZ varying from 2.0 to 2.4 $\mathrm{L} \mathrm{kg}^{-1}$ as reported by Thiele-Bruhn et al. [53], and from 5.2 to $10.5 \mathrm{~L} \mathrm{~kg}^{-1}$, as obtained by Leal et al. [56].

Although sulphachloropyridazine (SCP) is not as widely studied a sulphonamide as SMZ or SDZ, this drug has been extensively examined using various tests besides batch or laboratory column tests. The data available in the literature show a sorption potential in soil similar to that of other SAs. For example, Boxall et al. [58] reported low sorption coefficients for SCP in soil and a soil/slurry mixture ranging from 0.9 to $1.8 \mathrm{~L} \mathrm{~kg}^{-1}$. They also confirmed the high mobility of SCP in field studies, demonstrating the rapid transport of SCP to surface waters for concentrations as high as $590 \mathrm{\mu g} \mathrm{L}^{-1}$. Other studies are also consistent with this statement [38,44,52,56], giving $K_{d}$ values from 0.7 to $70.1 \mathrm{~L} \mathrm{~kg}^{-1}$.

Blackwell et al. [59], who also examined the leaching of SCP under field conditions, detected this compound in surface run-off samples even at a concentration of $25.9 \mu \mathrm{g} \mathrm{L}^{-1}$ following application at a rate of $1.18 \mathrm{~kg} \mathrm{ha}^{-1}$. These authors reported the occurrence of SCP in soil water samples at a concentration of $0.8 \mu \mathrm{g} \mathrm{L}^{-1}$ at $40 \mathrm{~cm}$ depth as long as 20 days after treatment. On the basis of their results the authors concluded that SCP poses a moderate risk of contaminating ground or surface water but that its potential to accumulate in soils is low. Further lysimeter- 
based studies by Blackwell et al. [60] sporadically detected SCP in leachate at levels from 0.7 to $8.5 \mu \mathrm{g} \mathrm{L}^{-1}$, depending on the irrigation conditions. SCP was applied in slurry $(197 \mathrm{~mL}$ per lysimeter), which corresponds to a SCP application rate of $5.2 \mathrm{mg}\left(1.18 \mathrm{~kg} \mathrm{ha}^{-1}\right)$. The authors concluded that this compound has the potential to reach ground and surface waters. On the basis of a lysimeter study, field investigations and laboratory column tests, Kay et al. [61,62,63] pointed out that soil tillage prior to slurry application can significantly reduce losses of SCP to tile drainage systems, thereby reducing the risk of surface water contamination by SCP residues in the slurry. The observed losses of SCP in a soil column with a soil surface broken as a result of tillage fell from $54.6 \%$ of the applied amount to zero [62].

Studies of sulphamethoxazole (SMX) have reported a similar sorption potential to that of SMZ [40]. With some exceptions, Leal et al. [56] recorded similar values of the distribution coefficient $K_{d}$ for both SMX and SMZ in an examination of thirteen soils. The results obtained by Yu et al. [64] are in agreement with that. These authors calculated a $K_{d}$ of $18.9 \mathrm{~L} \mathrm{~kg}^{-1}$ for one of three investigated soils. Their aim was to assess the suitability, inter alia, of SMX as a wastewater indicator. However, owing to the formation of non-extractable residues, such an application of SMX was regarded as limited. On the basis of a few investigations into the sorption of SMX to activated sludge, we can state that the sorption potential of sulphonamides to this sorbent is much greater than to soils [65-69]. Hrsing et al. [65] presented $K_{d}$ values for SMX ranging from 280 to $370 \mathrm{~L} \mathrm{~kg}^{-1}$, depending on the type of activated sludge. The results are consistent with the investigations of Hyland et al. [66], who studied the sorption of 75 pharmaceuticals onto activated sludge, obtaining a $K_{d}$ value of $269 \mathrm{~L} \mathrm{~kg}^{-1}$, or with those of Göbel et al. [67], who obtained a similar value of $K_{d}$ for SMX. In contrast, Yang et al. [68] reported a lower sorption of SMX to activated sludge $\left(K_{d}=28.6 \mathrm{~L} \mathrm{~kg}^{-1}\right)$. However, these differences may have arisen, for example, from the different methodologies used in the tests. Nevertheless, Yang et al. [68, 69] concluded that sorption of SAs to activated sludge is highly reversible (the amount retained after desorption is $0.9 \%$ of the original dose of $100 \mu \mathrm{g} \mathrm{L}-1)$. Therefore, the use of sewage sludge as fertilizer may constitute an additional source of SAs in ground and surface waters. Moreover, since SAs may be taken up by farmland crops, as demonstrated by Li et al. [70], the use of sewage sludge as fertilizer poses a serious risk to human health as well.

Knowledge of the sorption potential of other SAs like sulphathiazole (STZ), sulphapyridine (SPY), sulphamerazine (SMR), sulphadimethoxine (SDM), sulphamonomethoxine (SMM), sulphaguanidine (SGD) or sulphisoxazole (SSX) is very limited. In the literature there are only a few reports dealing with the sorption of these pharmaceuticals. $K_{d}$ for STZ adsorption onto soil particles ranges from 1.0 to $62.5 \mathrm{~L} \mathrm{~kg}^{-1}$ depending on soil properties [56]. In the case of SDM, Sanders et al. [71] pointed out that the linear sorption coefficient for SDM differs somewhat, ranging from 0.4 to $25.8 \mathrm{~L} \mathrm{~kg}^{-1}$ as a single solute and from 2.5 to $22.1 \mathrm{~L} \mathrm{~kg}^{-1}$ as a cosolute with ormetoprim, another antimicrobial. Moreover, the sorption of SDM was less linear in combination with ormetoprim. In turn, Maszkowska et al. [72] did not determine the influence of the co-solute on sulphonamide release. SDM exhibited a similar leaching behaviour from the soil when it was tested alone or in a mixture with SGD. Nevertheless, these authors also reported the considerable mobility of three SAs (SDM, SGD, SSX) in three different soils; SDM was released the slowest from the soil column. These results are consistent with 
those published previously by Białk-Bielińska et al. [43], who showed that SDM had a greater sorption potential than SGD $\left(K_{d}=0.3-107.5 \mathrm{~L} \mathrm{~kg}^{-1}\right.$ for SDM, $1.0-31.0 \mathrm{~L} \mathrm{~kg}^{-1}$ for SGD). SDM was also found to have the strongest tendency of all the SAs investigated to interact with activated sludge $[68,69]$. In addition, these authors investigated the sorption strength of sulphamonomethoxine (SMM) on activated sludge, finding a lower affinity of SMM than of SDM for activated sludge particles. Jin et al. [73] demonstrated the relatively high mobility of SDM in soil, obtaining a $K_{d}$ of $18.9 \mathrm{~L} \mathrm{~kg}^{-1}$. These authors also highlighted the influence of different co-contaminants on adsorption. They concluded that anionic surfactants and urea could adversely affect the sorption potential of SDM, whereas cationic surfactants could improve the retention of SDM on soil particles. Figueroa-Diva et al. [40] found that SMR exhibited the lowest level of sorption of the four SAs (SDM, SMX, SMZ and SMR) that they examined. According to Thiele-Bruhn et al. [53], SPY was the most strongly retained SA in the soil matrix, with $K_{d}$ higher than that of SMZ, SDZ and SDM.

Summing up, the available data indicate that determining the environmental fate of SAs in soils is not an easy task, as this depends largely on the physicochemical properties of soils and the chemical structures of the SAs. Nevertheless, one can infer from these results that these pharmaceuticals will tend to leach into ground or surface water rather than persist in soils. These data also show, however, that a certain amount of the SAs entering the soil can be retained there for quite a long time. Furthermore, their sorption to soils can increase or decrease depending on a number of different factors, which are discussed below.

\subsection{Factors influencing sorption of SAs to soils}

\subsubsection{Influence of the organic/mineral composition of soil}

Soils can be regarded as mixtures of mineral and organic fractions. The differences in their texture, structure, consistency, colour, chemical, biological and other characteristics arise from the type of parent material. Soils are therefore diverse matrices in which different sorption mechanisms can occur. The organic matter $(\mathrm{OM})$ content undoubtedly plays a critical role in the sorption capacity of soils [74]. Overall, in accordance with the available literature data, it has been shown that OM positively affects sorption strength of organic compounds. FigueroaDiva et al. [40] reported values of $K_{d}$ for all examined SAs increasing in the same sequence as the organic carbon content $\left(f_{\mathrm{OC}}\right)$ in the soils they investigated. Białk-Bielińska et al. [43] pointed out that SAs predominantly interact with soil OM by nonbonding van der Waals interactions and hydrogen bonding. Furthermore, such weak bonding forces are susceptible to desorption, resulting in the free release of SAs following their prior surface adsorption, an observation previously made by Thiele-Bruhn et al. [53]. The authors indicated that the influence of soil OM on adsorption depends not only on the organic carbon content, but also on its composition. Sukul et al. [39] demonstrated increased sorption of SDZ in soils in the presence of manure compared to soil without manure, which greatly emphasizes the role of dissolved OM and organomineral soil particles in SDZ sorption. On the basis of original research and literature available data, Hou et al. [75] demonstrated a positive relationship between $K_{d}$ and the organic carbon content $\left(f_{\mathrm{OC}}\right)$ for SMX sorption on soils/sediments with $f_{\mathrm{OC}}>2 \%$. However, for 
adsorbents with $f_{\mathrm{OC}}<2 \%$, a lower $f_{\mathrm{OC}}$ could result in increased sorption, suggesting competition between SMX and organic matter on mineral particles. Hyland et al. [66] confirmed the positive influence of organic matter on SA sorption. The high values of $K_{d}$ for SMX sorption onto activated sludge are fully justified, due in great part to the organic carbon (average $f_{\mathrm{OC}}=$ $44.1 \%$ ) in the sorbent. Leal et al. [56] analysed the influence of the OM and clay content on the sorption of several SAs, concluding that hydrophobic partition was important in SA sorption. Nevertheless, they also found that non-hydrophobic interactions with organic and/or mineral surfaces, mainly with $\mathrm{Al}$ and $\mathrm{Fe}$ oxides and hydroxides (abundant in the investigated soils) were also important in SA retention in soils. Boxall et al. [58] determined the influence of the type of mineral fraction in soil (clay or sand) on $K_{d}$. Their results showed that clay had a greater sorption capacity for SCP than sand. The same was reported by Ter Laak et al. [38], whose $K_{d}$ value for soil with greater amount of clay was twice as high as that for sandy soil. During field studies, however, Boxall et al. [58] reported faster leaching of SCP to ground water from a clay site than from a sandy site, an observation corroborated by Fan et al. [55]. The $K_{d}$ values for $\mathrm{SMZ}$ were positively related to the OM content in case of sorbents without sand. However, the latter authors' $K_{d}$ value was higher for sand (\%OM=0) than for soil containing OM. They explained this as having resulted from the transport of SAs on mobile colloids $(<2 \mu \mathrm{m}$, dissolved organic matter and clay-sized materials) in accordance with EPA [76], which resulted in faster elution from a soil column with OM content than from sand.

\subsubsection{Influence of $p H$}

In the context of the acid-base equilibrium of SAs, $\mathrm{pH}$ can strongly affect sorption. This has been confirmed in many investigations. The overall trend presented in the literature indicates decreasing sorption of SAs with increasing $\mathrm{pH}$. This is explained by the amphoteric nature of SAs, which consequently can occur in cationic, anionic or neutral form. The strongest possible interactions (ion-exchange mechanism) arise from competition for negatively charged sites on the soil surface between a cationic analyte and other cations present in the solute. Nevertheless, the existence of cationic SAs is limited due to the relatively low $p K_{a 2}$ value. Cation exchange is therefore not regarded as a favourable mechanism for SA sorption to soil matrices [39]. Although decreasing SA sorption is observed at high $\mathrm{pH}$, Sukul et al. [39] achieved relatively strong adsorption in the case of one soil at a $\mathrm{pH}$ where the anionic form of SDZ was dominant, claiming that this was due to possible partition to the positively charged surfaces of pedogenic oxides, very abundant in the clay fraction [39,53]. Kim et al. [42] and Białk-Bielińska et al. [43] also observed a negative correlation between $K_{d}$ and $\mathrm{pH}$. The former authors considered that the changes were better evident for soil with a greater OM content. Pinna et al. [77], in turn, did not observe such a strong dependence on OM content. The addition of cow manure $\left(f_{\mathrm{OC}}\right.$ $=30.58$ ) did not significantly affect antibiotic sorption to one of the investigated soils, but did increase the extent of sorption to another soil about three times, even though larger amounts of manure had been added to the first soil than to the second one. These authors concluded that the greater sorption to the second soil prior to the addition of cow manure was most probably due to the low $\mathrm{pH}$ of the soil suspension rather than to its high organic carbon content. On the other hand, the high $\mathrm{pH}$ of the first soil suspension (7.8) could have been responsible for the reduced sorption, despite the considerable amount of $\mathrm{OM}$ in this amended soil. 


\subsubsection{Influence of ionic strength}

Another environmentally important factor that can affect SA sorption is ionic strength. But this has not been examined extensively. Ter Laak et al. [38] carried out sorption studies of SCP, among other compounds. Generally speaking, they did not observe any significant influence of ionic strength, except in the case of one soil (clay loam), in which sorption doubled when the $\mathrm{CaCl}_{2}$ concentration was raised from 0.006 to $0.2 \mathrm{M}$. The authors concluded that this increase in sorption was probably due to the neutral form of SCP increasing from 3.3 to $8.3 \%$ because of the decreasing $\mathrm{pH}$. Protons are displaced from the cation-exchange sites by the addition of $\mathrm{Ca}^{2+}$ cations, which are ultimately responsible for the decrease in $\mathrm{pH}$. Elevated cation concentrations near negatively charged soil surfaces, resulting in a decrease in the electrostatic repulsion of negatively charged sorbate molecules and soil particles, is another explanation considered by those authors. Srinivasan et al. [44] reported the different behaviour of SMX under conditions of increasing ionic strength. They explained the increasing $K_{d}$ for SMX in the case of one soil as being due to cation bridging. Since positively charged calcium ions are present in the solution, bonding of anionic SMX to calcium is possible. In addition, the occurrence of a salting out effect, reducing the solubility of SMX in the salt solution so that it precipitates in the soil, was taken into consideration as a possible reason for the increase in sorption. The positive influence of ionic strength on sorption can also be attributed to the replacement of protons from the soil surface as the ionic strength increases, causing a slight reduction in $\mathrm{pH}$, and shifting acidic SMX towards neutral forms that are more strongly sorbed than the anionic forms. Two other soils examined by Srinivasan et al. [44] exhibited an opposite and irregular trend in sorptive affinity of SMX, with elevated ionic strengths resulting in decreased sorption coefficients of SMX in the case of both soils. A slight decrease in sorption with increasing ionic strength of solute was also observed by Białk-Bielińska et al. [43] in the case of SDM and SGD and three soils. Srinivasan et al. [44] concluded that the ionic composition plays an important role in the sorption of ionizable organic compounds. Nevertheless, they, too, highlighted the necessity for further research in view of the conflicting results published in the literature.

\subsection{Available data on the presence of SAs in soils}

Although many methods have been developed in the past decade for the analysis of SAs in aqueous matrices, only a few are described in the literature for the determination of these contaminants in soil matrices. This is because the chemical analysis of pharmaceuticals from soil matrices is complicated by the need for extraction. Hence, our knowledge about the quantity of SAs in solid matrices is still limited. Nevertheless, the available literature data indicate their occurrence in agricultural soils after conventional fertilization. In a two-year monitoring study Höper et al. [78] determined SMZ at a concentration of $11 \mu \mathrm{g} \mathrm{kg}^{-1}$. Pawelzick et al. [79] reported a maximum concentration of $4.5 \mu \mathrm{g} \mathrm{kg}^{-1}$ for SMZ; these results are in agreement with $\mathrm{Hu}$ et al. [80], who demonstrated the occurrence of SMX $\left(0.03-0.9 \mu \mathrm{gg}^{-1}\right)$ and SCP $\left(0.18-2.5 \mu \mathrm{g} \mathrm{kg}^{-1}\right)$. Karc1 et al. [81] found three SAs in agricultural soils in Turkey at concentrations even two orders of magnitude higher than those reported in previous studies: STZ $\left(0.05-0.4 \mathrm{mg} \mathrm{kg}^{-1}\right)$, SCP $\left(0.05-0.1 \mathrm{mg} \mathrm{kg}^{-1}\right)$ and SMX $\left(0.05-0.1 \mathrm{mg} \mathrm{kg}^{-1}\right)$. There are some 
discrepancies in the available literature data, which may be due to differences in the physicochemical properties of the solid samples examined. They may also stem from the intensity of fertilization and the initial quantities of SAs applied in animal husbandry. Nevertheless, even low concentrations of SAs reported in soil samples may contaminate other environmental compartments as a result of release via desorption.

In general, concentration limits of antibiotics in the environment are not regulated, even though growing public concern has been taken into account in the prescription of environmental risk assessments of veterinary pharmaceuticals in the USA and Europe [19-23]. For these reasons, it is still necessary to develop analytical methods for the quantitation of the most important SAs in soil samples: this will help to estimate the exposure potential as well as the concentration of these substances in the terrestrial environment. Nevertheless, for a full risk assessment of these compounds not only is an exposure assessment necessary but also a hazard characterization, which addresses the question whether a substance has the potential to cause harmful effects. This will be discussed below.

\section{Effects of sulphonamides in the soil environment}

\subsection{Introduction to soil ecotoxicology}

SAs are commonly present in agricultural soils, though in fairly low concentrations (ppb and ppt levels), and are continuously being released into the environment via several routes (e.g. grazing animal faeces, manure spreading, WTP effluents). Such a state of affairs requires an Environmental Risk Assessment investigation, which should answer the basic question of whether the presence of SAs in soils poses a hazard. Ecotoxicology is the discipline that addresses this issue. It encompasses the study of organisms, populations, communities and ecosystems in terms of exposure to chemical agents, i.e. their transfer from the environment to organisms and their toxic effects. Simply put, it is the science of assessing the effects of toxic substances on ecosystems in order to protect these as a whole, rather than particular compartments, such as populations or organisms. In a practical manner, besides toxic effects, ecotoxicology explores the occurrence, distribution, accumulation and dissipation of anthropogenic toxic substances in ecosystems. The fundamental tools for this kind of research are ecotoxicological tests [82-83].

\subsubsection{Ecotoxicological tests}

These tests are a special group of quantitative research methods based on a thorough assessment of the impact of toxic substances (single or mixtures) on living organisms. Quantification of the results enables us to estimate the cumulative toxicity and the interactions between the introduced substances [82]. Obtaining such data enables scientists to extrapolate the results and define safe concentration levels in the ERA process (which is described in greater detail in Section 4 of this chapter).

In order to prepare valid ecotoxicity tests numerous factors need to be considered, the main ones being exposure time (acute or chronic), type of medium used, target species, toxic 
substance concentration range and choice of endpoint (e.g. mortality, growth inhibition, respiration).

Some 60 years ago scientists realized the need to establish uniform, standard test procedures in order to increase the repeatability and comparability of data obtained from tests. Researchers publish their own designs for tests together with results, enabling others to mimic the conditions for further experiments and allowing a better comparison of the results. Until now many standardized test procedures have been established by various environmental and governmental organizations/institutions. The best-known of these are the Organization for Economic Cooperation and Development (OECD), International Standards Organization (ISO), American Public Health Association (APHA), Environmental Protection Agency (EPA), American Society for Testing and Materials (ASTM) and International Seed Testing Association (ISTA), as well as many others from non-English speaking countries, like the the German Institute for Standardization (Deutsches Institut für Normung - DIN) and Polish Norms (Polskie Normy - PN). With this in mind it is common practice to perform tests strictly according to a chosen norm, or to modify just some aspects of a method as and when the conditions require this $[82,84]$.

\subsubsection{Soil organisms in ecotoxicological studies}

The guidelines for ecotoxicological tests recommend using the best suited organisms. If the species stipulated in a guideline is unavailable, a similar one can be chosen, but it is important to select species that are extensively described in the literature. As species usually differ between ecosystems, their choice should take account of specific local conditions [82]. It is very important to realize that no single species is representative of all ecosystems; several singlespecies and multispecies tests have to be carried out in order to evaluate the behaviour of a toxic substance in an ecosystem.

Three main groups of organisms are evaluated in soil ecotoxicology: plants, microorganisms (microfauna) and animals (pedofauna). In the case of pedofauna, most ecotoxicological studies of soils are based on invertebrates and focus on worms, collembolans or enchytraeids because of their rapid reproduction times and easy maintenance. The most often examined endpoints here are weight change, survival, reproduction and behaviour (e.g. avoidance). Spermatophytes are the most popular plants, in which the measured effects usually relate to physiological disorders, growth inhibition and seed germination. Microorganisms constitute a very sensitive indicator of chemical stress as there are many parameters that can be evaluated: the usual ones are respiration, nitrification and growth. However (as in the case of SAs), microorganisms are also regularly evaluated for the occurrence and magnitude of increasing resistance towards pharmaceutical compounds [82-84].

\subsection{Available data on sulphonamide soil ecotoxicology}

An extensive literature review of data on SA soil toxicity has shown that there is a considerable gap in knowledge concerning the effects of these substances towards soil organisms. The vast majority of publications are dedicated to the analysis of microorganisms, followed by a small number of works on plants and just a few on pedofauna. Investigations involving the determination of quantified dose-response data (such as $\mathrm{EC}_{50}$ - the median effective concentration) 
are rare. However, rather more experiments have been done to detect the ecotoxicity of SAs (e.g. effects observed at a single concentration). Several investigations into the accumulation of these drugs in plants and the problem of bacterial resistance have also been done and are summarized below.

\subsubsection{Toxic effects of sulphonamides towards soil organisms}

Literature results in the form of a dose-response relationship concerning soil organisms affected by SAs are relatively scant in comparison to the numbers available for aquatic organisms. Nonetheless, such material as has been gathered does allow us to establish some basic trends and consider the potential risk posed by SAs in the soil environment. Table 2 lists effective concentrations of SAs towards soil organisms determined for different taxonomic groups. Some of the endpoints deemed less relevant have not been included in Table 2, but they will nevertheless be mentioned in the following section.

To make the results presented in Section 3.2. more transparent, all cited concentrations have been recalculated into ppm units. However, it is of paramount importance to bear in mind that each individual study was designed separately; this implies, for example, differences between the media (soil or liquid) used. Careful thought is therefore advisable in this respect as one could grossly over- or underestimate the inferences drawn from the results. On that account, for a more detailed inquiry, we recommend that the reader refer to the original versions of the cited papers.

The pedofauna is the most understudied group of soil organisms mentioned in the literature: there have been just a handful of studies. Very interesting experiments using SMX, SDZ, SPY and SMZ were conducted on the nematode Caenorhabditis elegans, where several kinds of effects were evaluated (behavioural - movement, and growth - body length) during 24 - 96 hours. The second generation, not exposed to SAs, was examined in the same manner. The results showed that SAs affected growth and behaviour in all the exposed nematodes in a time- and concentration-dependent way. Also, as one might expect, behavioural effects were more sensitive than growth in all cases. Interestingly though, transgenerational effects were observed: the unexposed progeny of the examined nematodes exhibited significant toxic effects. This was speculated to correspond to the ability of SMX, SDZ, SPY to penetrate the placenta and the secretion of SDZ, SPY and SMZ in maternal milk [85-86]. A different study group evaluated the effects of SCP in a multispecies soil system, where one of the examined endpoints was the mortality of earthworms Eisenia fetida. In this case no effect was observed for up to 21 days of exposure to SCP at concentrations reaching $100 \mathrm{ppm}$ [87].

Two independent groups performed studies of the potential impact of SMX and SMZ towards plant growth and soil quality. The plants investigated were rice Oryza sativa L., cucumber Cucumis sativus L., endive Cichorium endivia [88], lettuce Lactuca sativa, alfalfa Medicago sativa L. and carrot Daucus carota [89]. There are several differences between the approaches of the two groups, such as the time of exposure, range of concentrations or the types of tests used. Despite this, the results are comparable and some conclusions are shared. In all the investigations SMX and SMZ were deemed to have the potential to affect soil organisms in environmentally relevant concentrations. Seed germination was found to be an insensitive endpoint. One of the groups [88] evaluated seed germination using the root length of seedlings in order 
to obtain better results. In nearly all cases SMX was found to be more effective than SMZ. Rice and carrot were found to be the most sensitive organisms with respective $\mathrm{EC}_{10}$ values of 0.1 ppm and $0.011 \mathrm{ppm}$ [88-89]. Additionally, one group explored soil respiration and soil phosphatase activity: in these cases the respective $\mathrm{EC}_{10} \mathrm{~s}$ for SMX were $7 \mathrm{ppm}$ and 1 ppm [88]. The inference to be drawn here is that antibiotic residues in manure and soils may affect soil microbial and enzyme activities.

A relatively original investigation was performed to assess the impacts of anthropogenic stressors (i.a. SAs) on symbiotic plant-microbe relationships [90]. The authors studied the effects of SMX on the arbuscular mycorrhizal fungus Glomus intraradices grown on carrot $D$. carota root-organ cultures. The assay endpoints were root length (carrot), hyphae growth and spore production (fungus). The exposure period lasted up to 28 days and the highest concentration tested was $1 \mathrm{ppm}$. SMX was found to be effective at low concentrations towards both organisms: the respective $\mathrm{EC}_{50} \mathrm{~s}$ for carrot and fungus (hyphae growth) were 0.0454 and 0.0451 ppm. Assessment of the endpoints was as follows: root lengths responded quickly to the presence of phytotoxic pharmaceuticals in the culture medium; hyphae length was a sensitive endpoint after 21 days' exposure; spore production required 28 days' exposure before significant differences could be detected [90].

The toxicity of STZ towards soybean (Glycine max (L.) Merr.) was evaluated as a potential nitrification inhibitor [91]. The effects were measured according to the growth of these plants. Fresh weight and dry weight of roots and plant tops were measured. The concentration range for STZ reached $200 \mathrm{ppm}$. STZ drastically reduced both main root elongation and lateral root development, the suppression increasing concentration-wise. Effects on soybean plants were detectable but statistically non-significant at a concentration of $10 \mathrm{ppm}$. STZ $\mathrm{EC}_{50}$ for dry root yield was equal to $29.5 \mathrm{ppm}$. It is worth noting that STZ inhibited root growth more than top growth.

The effects of sulphamonomethoxine sodium (SMM-Na) and sulphadiazine sodium (SDZ-Na) were investigated in three plant species: wheat Triticum aestivum L., Chinese cabbage Brassica campestris L. and tomato Cyphomandra betacea [92]. All of the plants exhibited linear correlations between the effects (root and shoot elongation) and SA concentrations. Seed germination was also considered, but was not sensitive to toxicity within the chosen range of SA concentrations. The tests were conducted over 2-5 days. The data acquired showed that wheat was the plant most sensitive to the toxicity of SDZ-Na with an $\mathrm{IC}_{50}=28.1 \mathrm{ppm}$ and that cabbage was the most sensitive to SMM-Na with an $\mathrm{IC}_{50}=27.1 \mathrm{ppm}$. Worthy of note is the fact that in this study root and shoot elongation of the three crops exhibited different sensitivities, depending on the particular drug and plant species [92].

A study was developed specifically for SAs; it attempted to assess different susceptibility patterns of soil bacteria Pantoea agglomerans and standard antibiotic test bacteria Pseudomonas aeruginosa, depending on intercellular and environmental $\mathrm{pH}$ [93]. The results of the study revealed the effects at low concentrations (max. 20 ppm) of 8 SAs (SMX, STZ, SDZ, SDM, SMZ, SCP, SPY and SGD) at different $\mathrm{pH}$ values (from 5 to 8 ). The effects corresponding to the most sensitive $\mathrm{pH}$ values are listed in Table 2 . The brief conclusion of this work is that the effects of SAs on microbial soil populations may depend closely on the ability of the bacteria to regulate their intercellular $\mathrm{pH}$ [93]. 


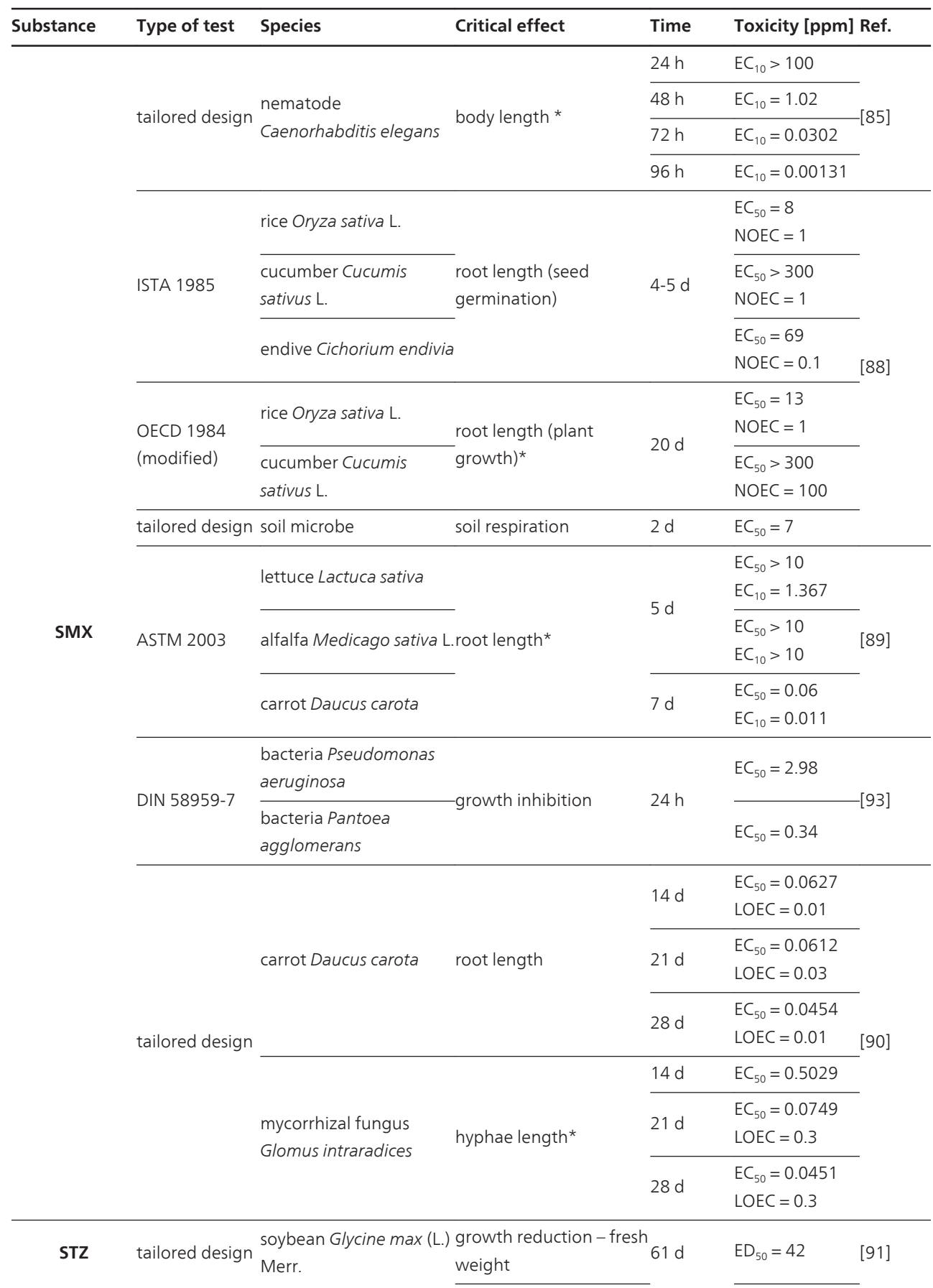




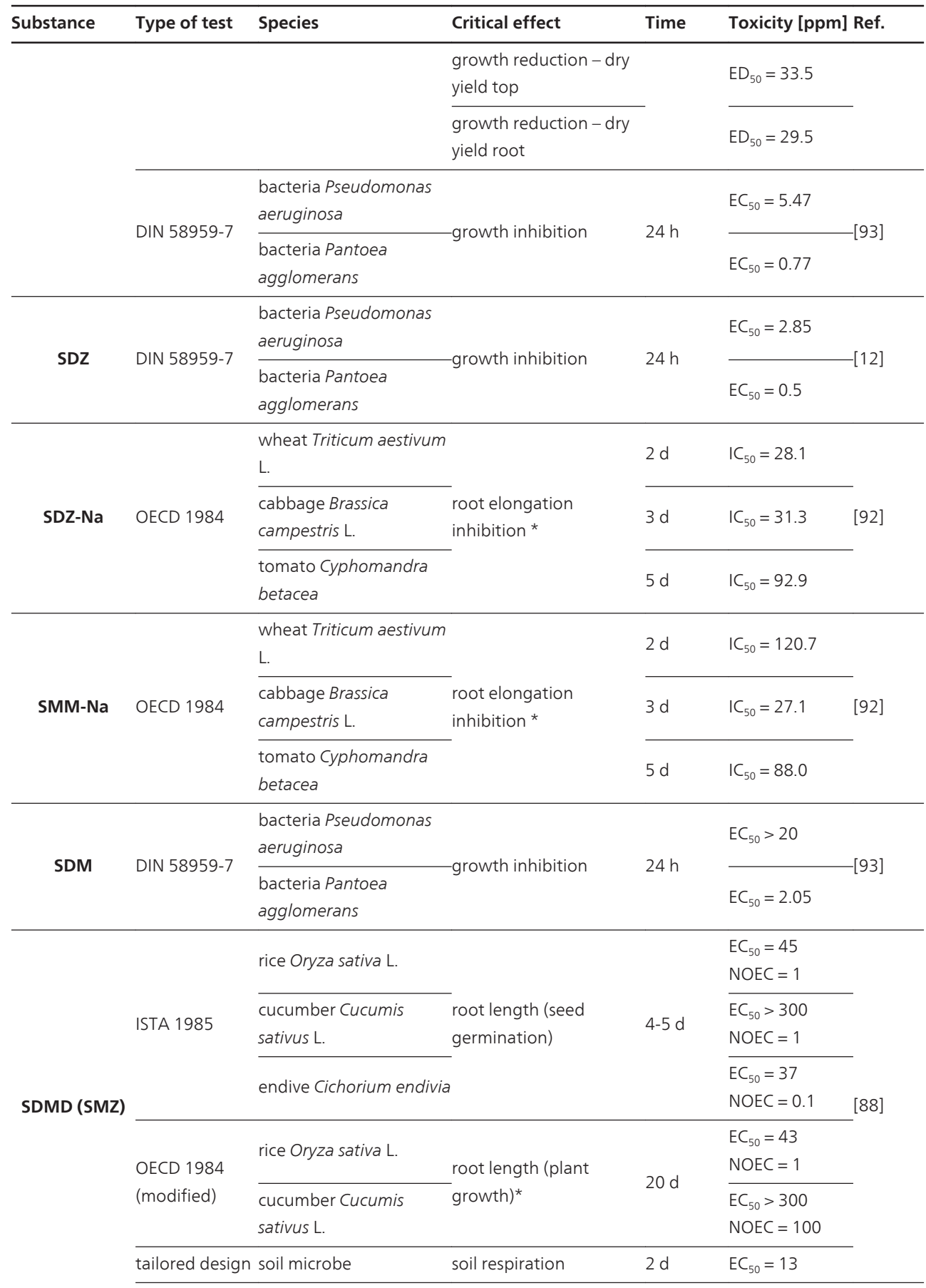




\begin{tabular}{|c|c|c|c|c|}
\hline Substance & Type of test & Critical effect & Time & Toxicity [ppm] Ref. \\
\hline & \multirow{6}{*}{ ASTM 2003} & \multirow{2}{*}{ lettuce Lactuca sativa } & \multirow{4}{*}{$5 d$} & $\mathrm{EC}_{50}>10$ \\
\hline & & & & $\mathrm{EC}_{10}=0.851$ \\
\hline & & \multirow{2}{*}{ alfalfa Medicago sativa L.root length* } & & $\mathrm{EC}_{50}>10$ \\
\hline & & & & $\mathrm{EC}_{10}=5.336$ \\
\hline & & \multirow{2}{*}{ carrot Daucus carota } & \multirow{2}{*}{$7 d$} & $E C_{50}>10$ \\
\hline & & & & $E C_{10}=0.065$ \\
\hline & \multirow{4}{*}{ DIN 58959-7 } & \multirow{4}{*}{$\begin{array}{l}\text { bacteria Pseudomonas } \\
\text { aeruginosa }\end{array}$} & \multirow{4}{*}{$24 \mathrm{~h}$} & $5 C-2$ \\
\hline & & & & $\mathrm{LC}_{50}>2$ \\
\hline & & & & - [93] \\
\hline & & & & $E C_{50}=1.14$ \\
\hline \multirow{4}{*}{ SCP } & \multirow{4}{*}{ DIN 58959-7 } & \multirow{4}{*}{$\begin{array}{l}\text { bacteria Pseudomonas } \\
\text { aeruginosa } \\
\text { bacteria Pantoea } \\
\text { agglomerans }\end{array}$} & \multirow{4}{*}{$24 \mathrm{~h}$} & $E S$ \\
\hline & & & & ${ }^{E} C_{50}$ \\
\hline & & & & [95] \\
\hline & & & & $\mathrm{EC}_{50}=0.48$ \\
\hline \multirow{3}{*}{ SPY } & \multirow{3}{*}{ DIN 58959-7 } & \multirow{3}{*}{$\begin{array}{l}\text { bacteria Pseudomonas } \\
\text { aeruginosa } \\
\text { bacteria Pantoea } \\
\text { agglomerans }\end{array}$} & \multirow{3}{*}{$24 \mathrm{~h}$} & $\mathrm{EC}_{50}>20$ \\
\hline & & & & 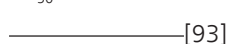 \\
\hline & & & & $\mathrm{EC}_{50}=2.22$ \\
\hline & \multirow{5}{*}{ DIN 58959-7 } & \multirow{5}{*}{$\begin{array}{l}\text { bacteria Pseudomonas } \\
\text { aeruginosa }\end{array}$} & \multirow{5}{*}{$24 \mathrm{~h}$} & \\
\hline \multirow{4}{*}{ SGD } & & & & $E C_{50}>20$ \\
\hline & & & & - $[93]$ \\
\hline & & & & $E C_{50}>20$ \\
\hline & & & & $2-50=<0$ \\
\hline
\end{tabular}

* this author also examined the results for several other endpoints - see Section 3.2.1.

Table 2. Sulphonamide soil ecotoxicology - literature review

\subsubsection{Other relevant soil ecotoxicology data}

Several publications by Migliore et al. have shed much light on the toxicity and bioaccumulation of SDM for different terrestrial plants [94-98]. The species included in the research belonged to two groups:

- crop plants Panicum miliaceum L., Pisum sativum L., Zea mays L. and Hordeum distichum L.

- weeds Amaranthus retroflexus L., Plantago major L., Rumex acetosella L and Lythrum salicaria L.

All the plants exhibited bioaccumulation and toxicity during post-germinative development at concentrations of $300 \mathrm{ppm}$, though of course to different extents. Lythrum salicaria L., exposed to lower concentrations, demonstrated a hormetic response. Crop plants accumulated SDM at dissimilar rates but always higher in roots than in foliage. In order to present the versatility of these results, those of additional research using other SAs and terrestrial plants are listed in Table 3. 


\begin{tabular}{|c|c|c|c|}
\hline Substance & Organism & Observed effects & Ref. \\
\hline SDM & $\begin{array}{l}\text { Panicum miliaceum L., Pisum sativum L., Zea mays L., } \\
\text { Hordeum distichum L., Amaranthus retroflexus L., } \\
\text { Plantago major L., Rumex acetosella L. and Lythrum } \\
\text { salicaria L. }\end{array}$ & $\begin{array}{l}\text { accumulation, growth inhibition, } \\
\text { hormesis }\end{array}$ & [94-98] \\
\hline $\begin{array}{l}\text { SDZ } \\
\text { SDM } \\
\text { SMZ }\end{array}$ & Salix fragilis L., Zea mays L., Hordeum vulgare L. & $\begin{array}{l}\text { accumulation, toxic effects (root } \\
\text { physiology impairment) }\end{array}$ & {$[101-103]$} \\
\hline $\begin{array}{l}\text { SDZ } \\
\text { SMX }\end{array}$ & $\begin{array}{l}\text { Brassica rapa L. and Lumbricus terrestris }\left({ }^{\mathrm{p}}\right) \text {, activated } \\
\text { sludge }(\mathrm{sm})\end{array}$ & $\begin{array}{l}\text { non-extractable residues - low uptake } \\
\text { by organisms }\end{array}$ & [104] \\
\hline SDZ & soil microorganisms & respiration inhibition, adaptation & [105] \\
\hline SDZ & Eisenia fetida $(\mathrm{p})$ & no accumulation (uptake detected) & [106] \\
\hline SDM & Rhizobium etli (sm)-Phaseolus vulgaris L. symbiosis & growth inhibition of both organisms & [107] \\
\hline $\begin{array}{l}\text { SDZ } \\
\text { SMZ } \\
\text { SMX }\end{array}$ & Brassica chinensis L. and soil microorganisms & $\begin{array}{l}\text { accumulation, soil microbial biomass } \\
\text { inhibition - higher effects for } \\
\text { combined pollution }\end{array}$ & {$[70]$} \\
\hline 12 SAs & Arthrobacter globiformis (sm) & no effect in $\mathrm{t}=4 \mathrm{~h}$ & {$[100]$} \\
\hline SMX & Salmonella typhimurium $(\mathrm{sm})$ & mutagenic activity & {$[108]$} \\
\hline SDZ & Zea mays L. and soil microorganisms & molecular-chemical pattern changes & [109] \\
\hline SDZ & soil microorganisms & $\begin{array}{l}\text { soil respiration and bacterial } \\
\text { community structure were influenced } \\
\text { only after the addition of glucose }\end{array}$ & [110] \\
\hline SDZ & soil microorganisms & soil community structure shift & [111] \\
\hline SDZ & Triticum aestivum $\mathrm{L}$. & accumulation (mainly in roots) & [112] \\
\hline SMZ & $\begin{array}{l}\text { Lupinus luteus, Pisum sativum L., Lens esculenta } \\
\text { Medik., Glycine max (L.) Merr., Vigna angularis, } \\
\text { Medicago sativa L. }\end{array}$ & $\begin{array}{l}\text { root growth inhibition, necrotic } \\
\text { changes, cytochrome c oxidase activity } \\
\text { shifts }\end{array}$ & [113] \\
\hline $\begin{array}{l}\text { SDM } \\
\text { SMX }\end{array}$ & Pisum sativum L., Cucumis sativus L. & accumulation (mainly in roots) & [114] \\
\hline SMX & Brassica campestris L. & minimal accumulation & {$[115]$} \\
\hline SMZ & $\begin{array}{l}\text { Lolium perenne L., Poa pratensis L., Poa trivialis L., } \\
\text { Nasturtium officinale R. Br. }\end{array}$ & accumulation & [116] \\
\hline $\begin{array}{l}\text { SDM } \\
\text { SMR }\end{array}$ & $\begin{array}{l}\text { Solanum tuberosum L., Daucus carota, Zea mays L., } \\
\text { Lycopersicon esculentum Mill. }\end{array}$ & accumulation & [117] \\
\hline SDZ & Lactuca sativa, Daucus carota & not detected in subject plants & [118] \\
\hline
\end{tabular}

All organisms in Table 3 belong to one of three groups: soil microorganisms (sm), pedofauna $\mathbf{( p )}$ or terrestrial plants.

Table 3. Simplified list of published SA soil ecotoxicology research 
As stated before soil microbiota is sensitive and easy to evaluate; hence, it is often examined for several target effects. In some cases, however, the results are closely dependent on incubation time - OECD 209 guidelines recommend relatively short exposure times which can lead to underestimated results. This issue has been mentioned by authors working with SAs [99-100]. Moreover, microorganisms are often not the primarily evaluated body in a test design. In fact effects on microbe communities are sought as additional results, helpful in monitoring the conditions in the test environment. Some research papers covering the soil ecotoxicity of SAs (not mentioned hitherto) are very briefly summarized in Table 3.

\subsubsection{Development of resistance of soil microorganisms to sulphonamides}

The current increasing interest in research into pharmaceutical residues in the environment has drawn the attention of scientists to the causation of bacterial resistance by antimicrobial residues. As the case of SA residues in terrestrial compartments is no exception, relevant research results have been published by several authors.

The effect of SCP together with pig slurry was examined during a three-week exposure, using Biolog ${ }^{\circledR}$ multiwall plates to determine pollution-induced community tolerance (PICT). Several physiological processes were monitored as well as community-level physiological profiling (CLPP) [119]. As a result of the tests it was established that the soil microbial community's tolerance increased as soon as 7 days following exposure. Indeed, a SCP concentration of 7 ppm was sufficient to trigger the first effects. An increase in tolerance has been reported for a procedure comparable to normal agricultural practice [119].

Several investigations have been conducted with SDZ in manure. It was established that such a combination synergistically increased antibiotic resistance in bacteria. Some of the explored variations of the tests included the use of a multispecies system (microcosm) with soil bacteria, the preparation of tests on different kinds of soil and multiple amendment with pig manure. SA resistance genes were detected using hybridization and the polymerase chain reaction (PCR). In all cases there was a significant increase in resistance, though differing in extent depending on the test design. Following amendment, the bacterial populations carrying the SA resistance genes introduced to the soil declined strongly in the first weeks; nonetheless, they have the potential to be present for several months [120-122].

Sulphamethoxazole (SMX) was also examined with respect to its effect on soil bacteria. Two methods were used to assess PICT: leucine incorporation and Biolog ${ }^{\circledR}$ plates. Community structure was assessed using phospholipid fatty acid (PLFA) analysis, CLPP and bacterial growth. No effect was seen at 1 ppm SMX. At higher concentrations (20 - 500 ppm) effects were significant but relatively small (a ca twofold increase in community tolerance). Nonetheless, the impact of SMX on soil reflected both the direct inhibition of bacterial growth rates and changes in community structure [123]. 


\section{Environmental risk assessment of veterinary pharmaceuticals (VPCs) in soil ecosystems}

Guidelines describing how the environmental risks of veterinary products should be assessed for a range of countries have been published [22]. The approach used in Europe is based on the recommendations of the International Co-operation on Harmonization of Technical Requirements for Registration of Veterinary Products (VICH), which has attempted to harmonize the environmental risk assessment requirements of veterinary products in the USA, Europe and Japan. The approach is a two-phase process [19-20,22]. According to these guidelines for the environmental risk assessment (ERA) of VPCs, the ERA process starts with an initial exposure assessment (Phase I). With some exceptions, a fate and effects analysis (Phase II) is only required when exposure-based thresholds, the so-called action limits, are exceeded in different environmental compartments. Thus, risk assessment, described by the Risk Quotient (RQ), is carried out by calculating the ratio of the predicted (or measured) environmental concentration (PEC or MEC respectively) and the predicted biological noneffective concentrations (PNEC) on non-target organisms. The PNEC is ultimately derived from the toxicity data by applying an assessment factor (AF), usually calculated as the ratio of $\mathrm{EC}_{50}$ or NOEC to AF. The assessment factor (in the range from 10 to 1000) takes into account interspecies variation, acute/subchronic to chronic extrapolation and laboratory data to field impact extrapolation. For example, for acute toxicity tests its value is 1000 . Nevertheless, if RQ is less than one, no further testing is recommended. Calculations of environmental concentrations rely on information on treatment dosage and intensity along with default values for standard husbandry practices and are based on a total residue approach reflecting worst-case assumptions. No fate and effects analysis is required for VPCs if the predicted environmental concentration in soil ( $\mathrm{PEC}_{\text {soil }}$ ) is $<100 \mu \mathrm{g} / \mathrm{kg}$ dry weight of soil. In this case the ERA is brought to a close. However, if $\mathrm{PEC}_{\text {soil }}$ is higher than the action limit, then Phase II, divided into two parts, comes into play: Tier A, in which the possible fate of the pharmaceutical or its metabolites and its effects on earthworms (mortality) and plants (germination and growth) as well as the effects of the test compound on the rate of nitrate mineralization in soil are determined; and Tier B, in which only effect studies are recommended for affected taxonomic levels (when RQ $>1$ or in the case of soil microorganisms an effect $>25 \%$ ); no further guidance on Tier B testing is provided. There are no requirements regarding the species of organisms that should be used at this stage apart from the statement that the study using terrestrial plants should be repeated on two additional species from the most sensitive species category in the Tier A study, in addition to repeating the study on the most sensitive species. However, if after Tier B testing $R Q$ is still $>1$, more studies may be needed in order to further elucidate the effects on terrestrial ecosystems [19-23].

The main problem associated with this approach is the fact that the no actual sales figures or measured environmental concentrations are at hand when a risk assessment is conducted. Therefore, only crude PEC calculations are performed [124]. Moreover, the (eco)toxicity tests in Phase II are carried out only for single compounds and on a limited range of species. As these compounds occur in natural media not as single, isolated drugs but usually together with 
other compounds of the same family or the same type, accumulated concentrations or synergistic-antagonistic effects need to be considered. For these reasons, Schmitt et al. suggested checking whether the current action limits are sufficiently protective for aquatic and terrestrial organisms by at least performing limit tests to confirm the absence of effects due to pharmaceuticals with PECs below the action limits [125]. Therefore, it seems to very important to check whether other pharmaceuticals do not also pose a threat to such organisms. In addition, it must be highlighted that contaminants in ecosystems can cause adverse effects, and that the severity of such effects is not dependent on the total substance concentration but on the bioavailable concentration of the xenobiotics. Therefore, the central concept for an assessment of soils should be the bioavailability representing the link between exposure and effect of contaminants. As a consequence a "bioavailability concept" was developed, which links environmental chemistry and ecotoxicology. According to Frische et al. [126] "bioavailability describes the complex processes of mass transfer and uptake of contaminants into soilliving organisms which are determined by substance properties, soil properties, the biology of organisms and climatic influence. The bioavailable contaminant fraction in soil represents the relevant exposure concentration for soil organisms". For these reasons, risk assessments and subsequent regulatory measures (permission to use chemicals, threshold values and redemption goals in soils) are particularly subject to considerable uncertainties as long as nominal and measured total concentrations are the basis of exposure assessment [126]. Owing to necessary extrapolations, the present non-consideration of bioavailability in practice can result in both over- and underestimating the risks posed by chemicals to soils, which is why it should be included in such an ecotoxicological test. To date, only a few authors have investigated the ecotoxicity potential of pharmaceuticals with respect to their bioavailability in soil samples (e.g. [127]).

\section{Risk assessment of sulphonamide residues in soil ecosystems}

The approach to risk evaluation of sulphonamides in the terrestrial environment, based on the discussed issues, is presented in Figure 2.

Although, as stated in Section 2, available studies have demonstrated that the sorption potential of SAs is low, this feature, along with their mobility, is strongly influenced by the physicochemical properties of soils, the ionic strength of soil solutions as well as the physicochemical properties of the drug itself. Hence, even a slight change in these parameters can greatly increase the immobilization of SAs in soil. Furthermore, it must be emphasized that SAs are continuously being released into terrestrial ecosystems; therefore, the kind of exposure of soil organisms may be subjected to will resemble that of traditional pollutants (e.g. pesticides, detergents), even those of limited persistence. Consequently, SAs (like other pharmaceuticals) may be considered pseudo-persistent, which explains why they are detected in soils, even at such high concentrations. For all the above reasons, the ERA of SAs is a very complex and difficult process. The simple approach defined in the available guidelines, while undoubtedly useful, may not be sufficient. In accordance with existing requirements [19-23] we present a calculation of RQ for three SAs, assuming the worst case scenario; maximum reported 


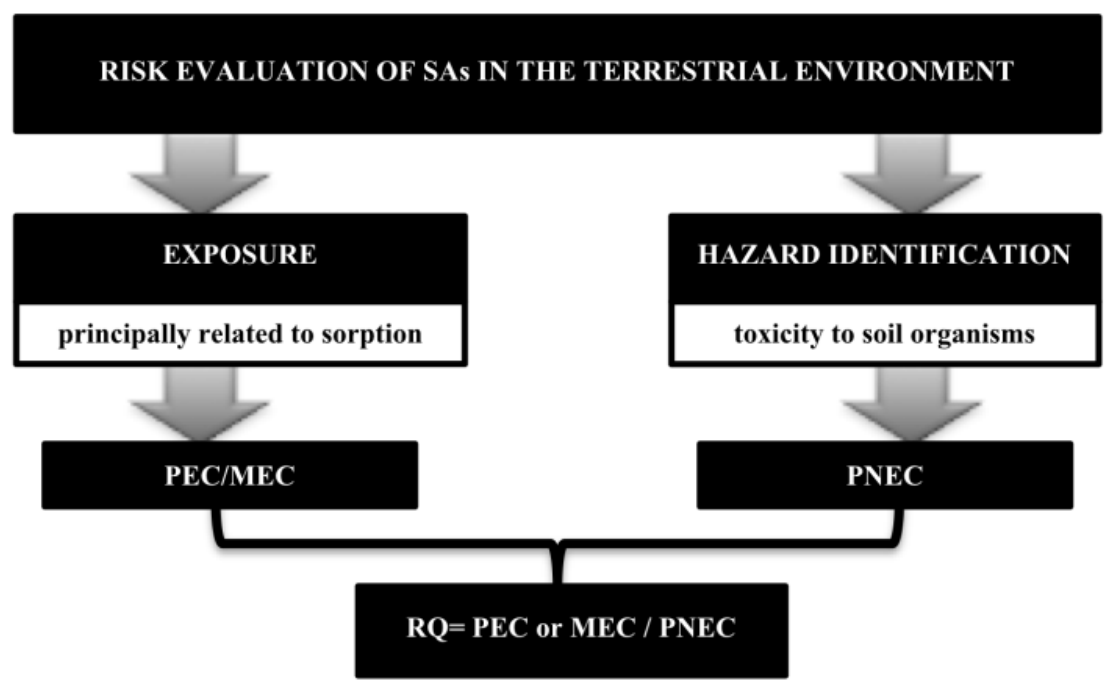

Figure 2. Risk evaluation of sulphonamides in the terrestrial environment

concentrations (Section 2.4) were used for the MEC value, PNEC was calculated on the basis of the data presented in Table 2, and AF was set at 1000 to ensure reliability (see Table 4).

\begin{tabular}{|c|c|c|c|c|}
\hline Substance & $\begin{array}{c}\text { MEC }_{\text {soil }} \\
{\left[\left(\mu \mathrm{kg}^{-1}\right]\right.}\end{array}$ & Organism & $\begin{array}{c}\text { PNEC }=\mathrm{EC}_{50} / \mathrm{AF} \\
(\mathrm{AF}=1000)\left[\mu \mathrm{gg}^{-1}\right]\end{array}$ & $\mathrm{RQ}=\mathrm{MEC} / \mathrm{PNEC}$ \\
\hline \multirow{4}{*}{ SMX } & \multirow{2}{*}{100} & rice Oryza sativa L. & 13 & 7.7 \\
\hline & & soil microbe & 7 & 14.3 \\
\hline & \multirow{2}{*}{0.9} & rice Oryza sativa L. & 13 & 0.07 \\
\hline & & soil microbe & 7 & 0.13 \\
\hline STZ & 400 & soybean Glycine max (L.) Merr. & 42 & 9.5 \\
\hline \multirow{4}{*}{ SMZ } & \multirow{2}{*}{11} & rice Oryza sativa L. & 43 & 0.25 \\
\hline & & soil microbe & 13 & 0.84 \\
\hline & \multirow{2}{*}{4.5} & rice Oryza sativa L. & 43 & 0.10 \\
\hline & & soil microbe & 13 & 0.35 \\
\hline
\end{tabular}

Table 4. RQ calculations for three $\mathrm{SAs}$ (RQs $>1$ are presented in bold)

The data presented in Table 4 support our above statement, as different RQs were obtained, depending on the data used in this evaluation. It seems that a single environmental concentration, which can differ in time and place, as well as the PEC values, which may also differ in different countries, can lead to the over- or underestimation of the risk posed by these 
compounds. Hence, in our opinion, more realistic (reliable) approaches should be incorporated that are based on data obtained from longer term monitoring studies in each country.

\section{Conclusions}

Our knowledge of the presence of SAs in soils is increasing, but information in the peerreviewed literature regarding the fate and ecotoxicological effects is still limited.

As sorption to the soil matrix governs the transport, persistence and (bio)availability of these chemicals in the environment, it can be assumed that low $K_{d}$ values, together with the physicochemical properties of these compounds, indicate that they are highly mobile, readily bioavailable and easily transported from soil surfaces to aquifers, causing surface- and groundwater contamination. Being readily bioavailable to micro-organisms, plants and animals, SAs can affect these directly; indeed, they have the potential to affect entire terrestrial ecosystems. The literature records the effects of many SAs on soil organisms, although these are mainly microorganisms and plants; as there are few data on pedofauna, it is impossible to form any clear judgment in this respect. SAs have been detected in soils, and the evidence points to possible effects on soil organisms at environmentally relevant concentrations. Furthermore, SAs can be accumulated by several terrestrial plants, such as the willow Salix fragilis L., which could be employed for the phytoremediation of SA-contaminated soils. However, some vegetables are also reported to accumulate SAs, which could lead to adverse effects along the food chain, ultimately affecting human health. Nevertheless, research into bioaccumulation as well as the phytoremediation of these compounds is still needed.

The most and least sensitive endpoints in plant studies are root length and seed germination respectively. The effects of SAs on microorganisms have been studied in many ways, e.g. with single species and multispecies designs, and different endpoints. Most of the available data show a strongly dose-dependent relationship for the explored endpoints. Moreover, their toxicity can be strongly influenced by the $\mathrm{pH}$ in the environment and organisms. Furthermore the issue of microorganisms developing antibiotic resistance is related to SAs. Especially when SA-contaminated manure is used, there is a noticeable increase in resistance genes.

Hardly any information has been found concerning the toxicity of SA mixtures in soils. Since these compounds are almost always present in the form of mixtures in the environment, this issue is one to be addressed in the future. Furthermore, there is a lack of data relating to the long-term exposure of non-target organisms, and especially how continuous exposure for several generations may affect a whole population.

In conclusion, the presented data on the fate and potential effects of SAs in the terrestrial environment appear to indicate a possible negative impact on soil ecosystems and imply a threat to public health. However, further studies are necessary to characterize the risk completely. 


\section{Abbreviations}

\begin{tabular}{|c|c|c|c|}
\hline Abbreviation & Full name & Abbreviation & Full name \\
\hline AF & Assessment Factor & PICT & Pollution-induced Community Tolerance \\
\hline APHA & \multicolumn{2}{|l|}{ American Public Health Association PN } & Polish Norms (Polskie Normy) \\
\hline ASTM & $\begin{array}{l}\text { American Society for Testing and } \\
\text { Materials }\end{array}$ & PNEC & Predicted Non-Effective Concentrations \\
\hline CLPP & $\begin{array}{l}\text { Community-level Physiological } \\
\text { Profiling }\end{array}$ & RQ & Risk Quotient \\
\hline DIN & $\begin{array}{l}\text { German Institute for } \\
\text { Standardization (Deutsches Institut } \\
\text { für Normung) }\end{array}$ & SA(s) & Sulphonamide(s) \\
\hline $\mathrm{EC}_{50}$ & Effective Concentration & SCP & Sulphachloropyridazine \\
\hline$E_{50}$ & Effective Dose & SDM & Sulphadimethoxine \\
\hline EMEA & $\begin{array}{l}\text { European Medicines Evaluation } \\
\text { Agency }\end{array}$ & SDMD (SMZ) & Sulphadimidine (Sulphamethazine) \\
\hline EPA & Environmental Protection Agency & SDZ & Sulphadiazine \\
\hline ERA & Environmental Risk Assessment & SGD & Sulphaguanidine \\
\hline $\mathrm{IC}_{50}$ & Inhibitory Concentration & SMM & Sulphamonomethoxine \\
\hline ISO & $\begin{array}{l}\text { International Organization for } \\
\text { Standardization }\end{array}$ & SMR & Sulphamerazine \\
\hline ISTA & $\begin{array}{l}\text { International Seed Testing } \\
\text { Association }\end{array}$ & SMX & Sulphamethoxazole \\
\hline LOEC & $\begin{array}{l}\text { Lowest Observed Effect } \\
\text { Concentration }\end{array}$ & SPY & Sulphapyridine \\
\hline MEC & $\begin{array}{l}\text { Measured Environmental } \\
\text { Concentration }\end{array}$ & SSX & Sulphisoxazole \\
\hline NOEC & $\begin{array}{l}\text { No Observable Effect } \\
\text { Concentrations }\end{array}$ & STZ & Sulphathiazole \\
\hline OECD & $\begin{array}{l}\text { Organization for Economic } \\
\text { Cooperation and Development }\end{array}$ & $\mathrm{VICH}$ & $\begin{array}{l}\text { Veterinary International Conference on } \\
\text { Harmonization }\end{array}$ \\
\hline OM & Organic Matter & VPCs & Veterinary pharmaceuticals \\
\hline pABA & p-aminobenzoic acid & WTP & Wastewater Treatment Plant \\
\hline PEC & $\begin{array}{l}\text { Predicted Environmental } \\
\text { Concentration }\end{array}$ & $f_{\text {oc }}$ & Organic Carbon Content \\
\hline
\end{tabular}

Table 5. List of abbreviations used in the text 


\section{Acknowledgements}

Financial support was provided by the Polish National Science Centre under grants DEC-2011/03/B/NZ8/03009 and DEC-2011/03/B/NZ8/03010 and DS 30-8110-D195-13.

\section{Author details}

Anna Białk-Bielińska, Joanna Maszkowska, Alan Puckowski and Piotr Stepnowski

Department of Environmental Analysis, Faculty of Chemistry, University of Gdańsk, Gdańsk, Poland

\section{References}

[1] Sukul P, Spiteller M. Sulphonamides in the environment as veterinary drugs. Reviews of Environmental Contamination and Toxicology 2006;187 67-101.

[2] Şanli S, Altun Y, Şanli N, Alsancak G, Baltran JL. Solvent Effects on pKa values of Some Substituted Sulphonamides in Acetonitrile-Water Binary Mixtures by the UVSpectroscopy Method. Journal of Chemical and Engineering Data 2009;54 3014-3021.

[3] Białk-Bielińska A, Stolte S, Matzke M, Fabiańska A, Maszkowska J, Kołodziejska M, Liberek B, Stepnowski P, Kumirska J. Hydrolysis of sulphonamides in aqueous solutions. Journal of Hazardous Materials 2012;221-222 264-274.

[4] Stoob K. Veterinary sulphonamide antibiotics in the environment: fate in grassland soils and transport to surface waters. PhD thesis. Swiss Federal Institute of Technology Zurich, Zurich; 2005.

[5] http://www.vcclab.org/lab/alogps/start.html (ALOGPS 2.1 program)

[6] http://www.syrres.com/what-we-do/databaseforms (SRC PhysProp Database)

[7] Babić S, Horvat AJM, Mutavdžić Pavlović D, Kaštelan-Macan M. Determination of $\mathrm{pK}_{\mathrm{a}}$ values of active pharmaceutical ingredients. Trends in Analytical Chemistry 2007;26 1043-1061.

[8] Carda-Broch S, Berthod A. Countercurrent chromatography for the measurement of the hydrophobicity of sulphonamide amphoteric compounds. Chromatographia 2004;59 79-87.

[9] Ruiz-Angel MJ, Carda-Broch S, García-Alvarez-Coque MC, Berthod A. Effect of ionization and the nature of the mobile phase in quantitative structure-retention relationship studies. Journal of Chromatography A 2005;1063 25-34. 
[10] García-Galán MJ, Díaz-Cruz MS, Barceló D. Identification and determination of metabolites and degradation products of sulphonamide antibiotics. Trends in Analytical Chemistry 2008;27 1008-1022.

[11] Reemtsma T, Jekel M. (Eds) Organic Pollutants in the Water Cycle. Wiley-VCh Verlag $\mathrm{GmbH} \&$ Co. KGaA, Weinheim, Germany, 2006.

[12] Ingerslev F, Halling-Sørensen B. Biodegradability properties of sulphonamides in activated sludge. Environmental Toxicology and Chemistry 2000;19 2467-2473.

[13] Kümmerer K. Antibiotics in the aquatic environment - A review - Part I, II. Chemosphere 2009;75 417-434.

[14] Park S, Choi K. Hazard assessment of commonly used agricultural antibiotics on aquatic ecosystems. Ecotoxicology 2008;17 526-538.

[15] García-Galán MJ, Díaz-Cruz MS, Barceló D. Combining chemical analysis and ecotoxicity to determine environmental exposure and assess risk from sulphonamides. Trends in Analytical Chemistry 2009;28 804-819.

[16] Schauss K, Focks A, Heuer H, Kotzerke A, Schmitt H, Thiele-Bruhn S, Smalla K, Wilke BM, Matthies M, Amelung W, Klasmeier J, Schloter M. Analysis, fate and effects of the antibiotic sulphadiazine in soil ecosystems. Trends in Analytical Chemistry 2009;28 612-618.

[17] Carlsson C, Johansson AK, Alvan G, Bergman K, Kühler T. Are pharmaceuticals potent environmental pollutants? Part II: Environmental risk assessments of selected pharmaceutical excipients. Science of the Total Environment 2006;364 67-87.

[18] Santos LHLM, Araújo AN, Fachini A, Pena A, Delerue-Matos C, Montenegro MCBSM. Ecotoxicological aspects related to the presence of pharmaceuticals in the aquatic environment. Journal of Hazardous Materials 2010;175 45-95.

[19] VICH, 2000. Guideline on environmental impact assessment (EIAS) for veterinary medicinal products - Phase I. VICH Topic GL6. International cooperation on harmonisation of technical requirements for registration of veterinary medicinal products.

[20] VICH, 2004. Guideline on environmental impact assessment for veterinary medicinal products - Phase II. VICH Topic GL38. International cooperation on harmonisation of technical requirements for registration of veterinary medicinal products.

[21] EMEA, 2007. Guideline on environmental impact assessment for veterinary medicinal products in support of the VICH guidelines GL6 and GL38. European Medicines Agency. Committee for medicinal products for veterinary use (CVMP). EMEA/ CVMP/ERA/418282/2005-Corr.

[22] EMEA, 2008a. Revised Guideline on environmental impact assessment for veterinary medicinal products in support of the VICH guidelines GL6 and GL38. European 
Medicines Agency. Committee for Medicinal Products for Veterinary Use (CVMP). EMEA/CVMP/ERA/418282/2005-Rev.1, 17 Nov. 2008.

[23] EMEA, 2008b. Reflection paper on the implementation of directive 2001/82/EC, as amended, in respect to the assessment of environmental risks of veterinary medicinal products. Committee for medicinal products for veterinary use (CVMP). Available: Doc. Ref. EMEA/CVMP/18112/2006-Consultation.

[24] Aga DS. (Ed) Fate of Pharmaceuticals in the Environment and in Water Treatment Systems. CRC Press Taylor \& Francis Group, Boca Raton- London-New York, 2008.

[25] Liu P, Zhu D, Zhang H, Shi X, Sun H, Dang F. Sorption of polar and nonpolar aromatic compounds to four surface soils of eastern China. Environmental Pollution 2008;156 1053-1060.

[26] OECD, 2000. Adsorption-desorption using a batch equilibrium method. OECD Guideline for the Testing of Chemicals 106. Organization for economic Cooperation and Development, Paris, France.

[27] Lopez Meza S, Garrabrants AC, van der Sloot H, Kosson DS. Comparison of the release of constituents from granular materials under batch and column testing. Waste Managment 2008;28 1853-1867.

[28] Delay M, Lager T, Schulz HD, Frimmel FH. Comparison of leaching tests to determine and quantify the release of inorganic contaminants in demolition waste. Waste Managment 2007;27 248-255.

[29] Grathwohl P, van der Sloot HA. Groundwater risk assessment at contaminated sites (GRACOS)๑: Test methods and modeling approaches. In: Quevauville P. (ed.) Groundwater Science and Policy, Cambridge: RSC; 2007.

[30] Grathwohl P, Susset B. Comparison of percolation to batch and sequential leaching tests: theory and data. Waste Managment 2009;29 2681-8.

[31] Delle A. Factors Affecting Sorption of Organic Compounds in Natural Sorbent/Water Systems and Sorption Coefficients for Selected Pollutants. A Review. Journal of Physical and Chemical Reference Data 2001;30(1) 187-439.

[32] Schwarzenbach RP, Gschwend PM, Imboden DM, Environmental Organic Chemistry, second ed. New Jersey, Hoboken: John Wiley \& Sons, Inc.; 2003.

[33] Weber WJ, McGinley PM, Katz LE. A Distributed Reactivity Model for Sorption by Soils and Sediments. 1. Conceptual Basis and Equilibrium Assessments. Environmental Science and Technology 1992;26, 1955-1962.

[34] Giles CH, Smith D, Huitson J. A general treatment and classification of the solute adsorption isotherm. I. Theoretical. Journal of Colloid and Interface Science 1974;47 755-765. 
[35] Farrell J, Reinhard M. Desorption of Halogenated Organics from Model Solids, Sediments, and Soil under Unsaturated Conditions. 1. Isotherms. Environmental Science and Technology 1994;28 53-62.

[36] Haque R, Coshow WR. Adsorption of Isocil and Bromacil from Aqueous Solution onto Some Mineral Surfaces. Environmental Science and Technology 1971;5(2) 139-141.

[37] Williams MC, Saison CLA, Williams D, Kookana R. Can aquatic distribution of human pharmaceuticals be related to pharmacological data? Chemosphere 2006; 65 2253-2259.

[38] Ter Laak TL, Gebbink WG, Tolls J. The effect of $\mathrm{pH}$ and ionic strength on the sorption of sulfachloropyridazine, tylosin, and oxytetracycline to soil. Environmental Toxicology and Chemistry 2006;25 904-911.

[39] Sukul P, Lamshöft M, Zühlke S, Spiteller M. Sorption and desorption of sulfadiazine in soil and soil-manure systems. Chemosphere 2008;73 1344-1350.

[40] Figueroa-Diva R, Vasudevan D, MacKay A. Trends in soil sorption coefficients within common antimicrobial families. Chemosphere 2010;79:786-793.

[41] Kurwadkar ST, Adams CD, Meyer MT, Kolpin DW. Comparative mobility of sulfonamides and bromide tracer in three soils. Journal of Environmental Management 2011;92 1874-1881.

[42] Kim Y, Lim S, Han M, Cho J. Sorption characteristics of oxytetracycline, amoxicillin, and sulfathiazole in two different soil types. Geoderma 2012;185-186 97-101.

[43] Białk-Bielińska A, Maszkowska J, Mrozik W, Bielawska A, Kołodziejska M, Palavinskas R, Stepnowski P, Kumirska J. Sulfadimethoxine and sulfaguanidine: their sorption potential on natural soils. Chemosphere 2012;86 1059-1065.

[44] Srinivasan P, Sarmah AK, Manley-Harris M. Co-contaminants and factors affecting the sorption behaviour of two sulfonamides in pasture soils. Environmental Pollution 2013;180 165-172.

[45] Doretto KM, Rath S. Sorption of sulfadiazine on Brazilian soils. Chemosphere 2013;90 2027-2034.

[46] Thiele-Bruhn S. Pharmaceutical antibiotic compounds in soils - a review. Journal of Plant Nutrition and Soil Science 2003;166 145-167.

[47] Beausse J. Selected drugs in solid matrices: a review of environmental determination, occurrence and properties of principal substances. Trends in Analytical Chemistry 2004;23 753-761.

[48] Tolls J. Critical Review Sorption of Veterinary Pharmaceuticals in Soils@: A Review. Environmental Science and Technology 2001;35(17) 3397-3406. 
[49] Baran W, Adamek E, Ziemiańska J, Sobczak A. Effects of the presence of sulfonamides in the environment and their influence on human health. Journal of Hazardous Materials 2011;196 1-15.

[50] Langhammer J-P. Untersuchungen zum Verbleib antimikrobiell wirksamer Arzneistoffe als Rückstände in Gülle und im landwirtschaftlichen Umfeld. PhD thesis. University of Bonn, Germany. 1989.

[51] Thurman E, Lidsey M. Transport of antibiotics in soil and their potential for groundwater contamination: conference proceedings, May 21-25, 2000. 3rd SETAC World Meeting, Brighton, UK; 2000.

[52] Tolls J, Gebbink W, Cavallo R. pH-dependence of sulphonamide antibiotic sorption: data and model evaluation: conference proceedings: 12-16 May, 2002, SETAC Europe 12th Annual Meeting, Vienna, Austria; 2002.

[53] Thiele-Bruhn S, Seibicke T, Schulten H-R, Leinweber P. Sorption of Sulfonamide Pharmaceutical Antibiotics on Whole Soils and Particle-Size Fractions. Journal of Environment Quality 2004;33 1331-1342.

[54] Lertpaitoonpan W, Ong SK, Moorman TB. Effect of organic carbon and $\mathrm{pH}$ on soil sorption of sulfamethazine. Chemosphere 2009;76 558-564.

[55] Fan Z, Casey FXM, Hakk H, Larsen GL, Khan E. Sorption, Fate, and Mobility of Sulfonamides in Soils. Water Air and Soil Pollution 2010;218 49-61.

[56] Leal RMP, Alleoni LRF, Tornisielo VL, Regitano JB. Sorption of fluoroquinolones and sulfonamides in 13 Brazilian soils. Chemosphere (2013), http://dx.d oi.org/10. 1016/ j.ch emosphere.2013.03.01 8

[57] Wehrhan A, Kasteel R, Simunek J, Groeneweg J, Vereecken H. Transport of sulfadiazine in soil columns: experiments and modelling approaches. Journal of Contaminant Hydrology 2007;89 107-135.

[58] Boxall ABA, Blackwell PA, Cavallo R, Kay P, Tolls J. The sorption and transport of a sulphonamide antibiotic in soil systems. Toxicology Letters 2002;131 19-28.

[59] Blackwell PA, Kay P, Boxall ABA. The dissipation and transport of veterinary antibiotics in a sandy loam soil. Chemosphere 2007;67 292-299.

[60] Blackwell PA, Kay P, Ashauer R, Boxall ABA. Effects of agricultural conditions on the leaching behaviour of veterinary antibiotics in soils. Chemosphere 2009;75 13-19.

[61] Kay, P, Blackwell, PA, Boxall, ABA. Fate of veterinary antibiotics in a macroporous tile drained clay soils. Environmental Toxicology and Chemistry 2004;23 1136-1144.

[62] Kay P, Blackwell PA, Boxall ABA. Column studies to investigate the fate of veterinary antibiotics in clay soils following slurry application to agricultural land. Chemosphere 2005;60 497-507. 
[63] Kay P, Blackwell PA, Boxall ABA. A lysimeter experiment to investigate the leaching of veterinary antibiotics through a clay soil and comparison with field data. Environmental Pollution 2005;134 333-341.

[64] Yu L, Fink G, Wintgens T, Melin T, Ternes TA. Sorption behavior of potential organic wastewater indicators with soils. Water Research 2009;43 951-960.

[65] Hörsing M, Ledin A, Grabic R, Fick J, Tysklind M, la Cour Jansen J,Andersen HR. Determination of sorption of seventy-five pharmaceuticals in sewage sludge. Water Research 2011;45 4470-82.

[66] Hyland KC, Dickenson ER V, Drewes JE, Higgins CP. Sorption of ionized and neutral emerging trace organic compounds onto activated sludge from different wastewater treatment configurations. Water Research 2012;46 1958-1968.

[67] Göbel A, Thomsen A, McArdell CS, Joss A, Giger W. Occurrence and sorption behavior of sulfonamides, macrolides, and trimethoprim in activated sludge treatment. Environmental Science and Technology 2005;39(11) 3981-3989.

[68] Yang S-F, Lin C-F, Lin AY-C, Hong P-KA. Sorption and biodegradation of sulfonamide antibiotics by activated sludge: experimental assessment using batch data obtained under aerobic conditions. Water Research 2011;45 3389-3397.

[69] Yang S-F, Lin C-F, Wu C-J, Ng K-K, Lin AY-C, Hong P-KA. Fate of sulfonamide antibiotics in contact with activated sludge-sorption and biodegradation. Water Research 2012;46 1301-1308.

[70] Li X, Yu H, Xu S, Hua R. Uptake of three sulfonamides from contaminated soil by pakchoi cabbage. Ecotoxicology and Environmental Safety 2013;92 297-302.

[71] Sanders S, Srivastava P, Feng Y, Dane J, Basile J, Barnett M. Sorption of the veterinary antimicrobials sulfadimethoxine and ormetoprim in soil. Journal of Environment Quality 2008;37 1510-1518.

[72] Maszkowska J, Kołodziejska M, Białk-Bielińska A, Mrozik W, Kumirska J, Stepnowski P, Krüger O, Kalbe U. Column and batch tests of sulfonamide leaching from different types of soil. Journal of Hazardous Materials 2013;260 468-474.

[73] Jin C, Pi Y, Wu C, Xue W, Chen Q, Liu J. Influence of four environmental substances on adsorption behavior of sulfamonometoxine in the soil. Acta Agriculturae Zhejiangensis 2013;25 130-134.

[74] Birkeland P. Soils and Geomorphology. Third ed. New York: Oxford University Press; 1999.

[75] Hou J, Pan B, Niu X, Chen J, Xing B. Sulfamethoxazole sorption by sediment fractions in comparison to pyrene and bisphenol A. Environmental Pollution 2010;158 2826-2832. 
[76] EPA; 1999. Understanding variation in partition coefficient, $\mathrm{Kd}$, values, volume I: the $\mathrm{Kd}$ model, methods of measurement, and application of chemical reaction codes. Washington, D.C.: Office of Air and Radiation, Environmental Protection Agency.

[77] Pinna MV, Castaldi P, Deiana P, Pusino A, Garau G. Sorption behavior of sulfamethazine on unamended and manure-amended soils and short-term impact on soil microbial community. Ecotoxicology and Environmental Safety 2012;84 234-242.

[78] Höper H, Kues J, Nau H, Hamscher G. Eintrag und Berbleib von Tierarzneimittelwirkstoffen in Böden. Bodenschutz 2002;4 141-148.

[79] Pawelzick HT, Höper H, Nau H, Hamscher G. A survey of the occurrence of various tetracyclines and sulfamethazine in sandy soils in northwestern Germany fertilized with liquid manure; conference proccedings: 18-22 April, 2004, SETAC Europe 14th Annual Meeting,, Prague, Czech Republic; 2004.

[80] Hu X, Zhou Q, Luo Y. Occurrence and source analysis of typical veterinary antibiotics in manure, soil, vegetables and groundwater from organic vegetable bases, northern China. Environmental Pollution 2010;158 2992-2998.

[81] Karci A, Balcioğlu IA. Investigation of the tetracycline, sulfonamide, and fluoroquinolone antimicrobial compounds in animal manure and agricultural soils in Turkey. The Science of the Total Environment 2009;407 4652-4664.

[82] Traczewska TM. Biologiczne metody oceny skażenia środowiska. Wrocław: Oficyna Wydawnicza Politechniki Wrocławskiej; 2011.

[83] Cardoso EJBN, Alves PRL. Soil Ecotoxicology. In: Begum G, (ed.). Ecotoxicology, InTech; 2012, p27-50.

[84] Van Gestel CAM. Soil ecotoxicology: state of the art and future directions. ZooKeys 2012;176 275-296.

[85] Yu Z, Jiang L, Yin D. Behavior toxicity to Caenorhabditis elegans transferred to the progeny after exposure to sulphamethoxazole at environmentally relevant concentrations. Journal of Environmental Sciences 2011;23(2) 294-300.

[86] Yu Z, Zhang J, Chen X, Yin D, Deng H. Inhibitions on the behavior and growth of the nematode progeny after prenatal exposure to sulphonamides at micromolar concentrations. Journal of Hazardous Materials 2013;250-251 198-203.

[87] Boleas S, Alonso C, Pro J, Babin M, Fernández C, Carbonell G, Tarazona JV. Effects of Sulphachloropyridazine in MS 3-Arable Land: A Multispecies Soil System for Assessing the Environmental Fate and Effects of Veterinary Medicines. Environmental Toxicology and Chemistry 2005;24(4) 811-819.

[88] Liu F, Ying G-G, Tao R, Zhao J-L, Yang J-F, Zhao L-F. Effects of six selected antibiotics on plant growth and soil microbial and enzymatic activities. Environmental Pollution 2009;157 1636-1642. 
[89] Hillis DG, Fletcher J, Solomon KR, Sibley PK. Effects of Ten Antibiotics on Seed Germination and Root Elongation in Three Plant Species. Archives of Environmental Contamination and Toxicology 2011;60 220-232.

[90] Hillis DG, Antunes P, Sibley PK, Klironomos JN, Solomon KR. Structural responses of Daucus carota root-organ cultures and the arbuscular mycorrhizal fungus, Glomus intraradices, to 12 pharmaceuticals. Chemosphere 2008;73 344-352.

[91] Maftoun M, Sheibany B. Comparative Phytotoxicity of Several Nitrification Inhibitors to Soybean Plants. Journal of Agricultural and Food Chemistry 1979;27 13651368 .

[92] Jin C, Chen Q, Sun R, Zhou Q, Liu J. Eco-toxic effects of sulphadiazine sodium, sulphamonomethoxine sodium and enrofloxacin on wheat, Chinese cabbage and tomato. Ecotoxicology 2009;18 878-885.

[93] Tappe W, Zarfl C, Kummer S, Burauel P, Vereecken H, Groeneweg J. Growth-inhibitory effects of sulphonamides at different $\mathrm{pH}$ : Dissimilar susceptibility patterns of a soil bacterium and a test bacterium used for antibiotic assays. Chemosphere 2008;72 836-843.

[94] Migliore L, Brambilla G, Cozzolino S, Gaudio L. Effect on plants of sulphadimethoxine used in intensive farming (Panicum miliaceum, Pisum sativum and Zea mays). Agriculture, Ecosystems and Environment 1995;52 103-110.

[95] Migliore L, Brambilla G, Civitareale C, Cozzolino S, Gaudio L. Effect of sulphadimethoxine contamination on barley (Hordeum distichum L., Poaceae, Liliopsida). Agriculture, Ecosystems and Environment 1996;60 121-128.

[96] Migliore L, Civitareale C, Brambilla G, Cozzolino S, Casoria P, Gaudio L. Effects of sulphadimethoxine on cosmopolitan weeds (Amaranthus retroflexus L., Plantago major L. and Rumex acetosella L.). Agriculture, Ecosystems and Environment 1997;65 163168.

[97] Migliore L, Civitareale C, Cozzolino S, Casoria P, Brambilla G, Gaudio L. Laboratory models to evaluate phytotoxicity of sulphadimethoxine on terrestrial plants. Chemosphere 1998;37 2957-2961.

[98] Migliore L, Rotini A, Cerioli NL, Cozzolino S, Fiori M. Phytotoxic Antibiotic Sulphadimethoxine Elicits a Complex Hermetic Response in The Weed Lythrum salicaria L. Dose-response 2010;8 414-427.

[99] Kümmerer K, Alexy R, Hüttig J, Schöll A. Standardized tests fail to assess the effects of antibiotics on environmental bacteria. Water Research 2004;38 2111-2116.

[100] Białk-Bielińska A, Stolte S, Arning J, Uebers U, Böschen A, Stepnowski P, Matzke, M. Ecotoxicity evaluation of selected sulphonamides. Chemosphere 2011;85 928-933. 
[101] Michelini L, Meggio F, La Rocca N, Ferro S, Ghisi R. Accumulation and Effects of Sulphadimethoxine in Salix fragilis L. Plants: A Preliminary Study to Phytoremediation Purposes. International Journal of Phytoremediation 2012;14(4) 388-402.

[102] Michelini L, Reichel R, Werner W, Ghisi R, Thiele-Bruhn S. Sulphadiazine Uptake and Effects on Salix fragilis L. and Zea mays L. Plants. Water, Air, \& Soil Pollution 2012;223 5243-5257.

[103] Michelini L, La Rocca N, Rascio N, Ghisi R. Structural and functional alterations induced by two sulphonamide antibiotics on barley plants. Plant Physiology and Biochemistry 2013;67 55-62.

[104] Heise J, Höltge S, Schrader S, Kreuzig R. Chemical and biological characterization of non-extractable sulphonamide residues in soil. Chemosphere 2006;65 2352-2357.

[105] Kotzerke A, Sharma S, Schauss K, Heuer H, Thiele-Bruhn S, Smalla K, Wilke BM, Scholter M. Alterations in soil microbial activity and $N$-transformation processes due to sulphadiazine loads in pig-manure. Environmental Pollution 2008;153 315-322.

[106] Norr C, Riepert F. Bioaccumulation Studies with Eisenia fetida Using an Established Degradation Test System. Journal of Soils and Sediments 2007;7(6) 393-397.

[107] Sartorius M, Riccio A, Cermola M, Casoria P, Patriarca EJ, Taté R. Sulphadimethoxine inhibits Phaseolus vulgaris root growth and development of $\mathrm{N}$-fixing nodules. Chemosphere 2009;76 306-312.

[108] Isidori M, Lavorgna M, Nardelli A, Pascarella L, Parrella A. Toxic and genotoxic evaluation of six antibiotics on non-target organisms. Science of the Total Environment 2005;346 87-98.

[109] Reichel R, Rosendahl I, Peeters ETHM, Focks A, Groeneweg J, Bierl R, Schlichting A, Amelung W, Thiele-Bruhn S. Effects of slurry from sulphadiazine- (SDZ) and difloxacin- (DIF) medicated pigs on the structural diversity of microorganisms in bulk and rhizosphere soil. Soil Biology and Biochemistry 2013;62 82-91.

[110] Zielezny Y, Groeneweg J, Vereecken H, Tappe W. Impact of sulphadiazine and chlorotetracycline on soil bacterial community structure and respiratory activity. Soil Biology and Biochemistry 2006;38 2372-2380.

[111] Hammesfahr U, Heuer H, Manzke B, Smalla K, Thiele-Bruhn S. Impact of the antibiotic sulphadiazine and pig manure on the microbial community structure in agricultural soils. Soil Biology and Biochemistry 2008;40 1583-1591.

[112] Grote M, Schwake-Anduschus C, Michel R, Stevens H, Heyser W, Langenkamper G, Betsche T, Freitag M. Incorporation of veterinary antibiotics into crops from manured soil. Landbauforschung Völkenrode 2007;57 25-32. 
[113] Piotrowicz-Cieślak AI, Adomas B, Nałecz-Jawecki G, Michalczyk DJ. Phytotoxicity of Sulphamethazine Soil Pollutant to Six Legume Plant Species. Journal of Toxicology and Environmental Health Part A 2010;73(17-18) 1220-1229.

[114] Tanoue R, Sato Y, Motoyama M, Nakagawa S, Shinohara R, Nomiyama K. Plant Uptake of Pharmaceutical Chemicals Detected in Recycled Organic Manure and Reclaimed Wastewater. Journal of Agricultural and Food Chemistry 2012;60 1020310211.

[115] Holling CS, Bailey JL, Heuvel B Vanden, Kinney CA. Uptake of human pharmaceuticals and personal care products by cabbage (Brassica campestris) from fortified and biosolids-amended soils. Journal of Environmental Monitoring 2012;14 3029-3036.

[116] Chitescu CL, Nicolau AI, Stolker AAM. Uptake of oxytetracycline, sulphamethoxazole and ketoconazole from fertilised soils by plants. Food Additives \& Contaminants: Part A 2012;DOI: 10.1080/19440049.2012.725479 1-9.

[117] Sabourin L, Duenk P, Bonte-Gelok S, Payne M, Lapen DR, Topp E. Uptake of pharmaceuticals, hormones and parabens into vegetables grown in soil fertilized with municipal biosolids. Science of the Total Environment 2012;431 233-236.

[118] Boxall ABA., Johnson P, Smith EJ, Sinclair CJ, Stutt E, Levy LS. Uptake of Veterinary Medicines from Soils into Plants. Journal of Agricultural and Food Chemistry 2006;54 2288-2297.

[119] Schmitt H, Haapakangas H, Van Beelen P. Effects of antibiotics on soil microorganisms: time and nutrients influence pollution-induced community tolerance. Soil Biology and Biochemistry 2005;37 1882-1892.

[120] Heuer H, Smalla K. Manure and sulphadiazine synergistically increased bacterial antibiotic resistance in soil over at least two months. Environmental Microbiology 2007;9 657-666.

[121] Heuer H, Focks A, Lamshöft M, Smalla K, Matthies M, Spiteller M. Fate of sulphadiazine administered to pigs and its quantitative effect on the dynamics of bacterial resistance genes in manure and manured soil. Soil Biology and Biochemistry 2008;40 1892-1900.

[122] Heuer H, Solehati Q, Zimmerling U, Kleineidam K, Schloter M, Müller T, Focks A, Thiele-Bruhn S, Smalla K. Accumulation of Sulphonamide Resistance Genes in Arable Soils Due to Repeated Application of Manure Containing Sulphadiazine. Applied and Environmental Microbiology 2011;77 2527-2530.

[123] Demoling LA, Bååth E, Greve G, Wouterse M, Schmitt H. Effects of sulphamethoxazole on soil microbial communities after adding substrate. Soil Biology and Biochemistry $2009 ; 41840-848$.

[124] Ankley GT, Brooks BW, Huggett DB, Sumpter JP. Repeating history: Pharmaceuticals in the environment. Environmental Science and Technology 2007;15 8211-8217. 
[125] Schmitt H, Boucard T, Garric J, Jensen J, Parrott J, Péry A, Römbke J, Straub JO, Hutchinson TH, Sánchez-Argüello P, WennmalmÅ, Duis K. Recommendations on the Environmental Risk Assessment of Pharmaceuticals - effect characterization. Integrated Environmental Assessment and Management 2010;6 588-602.

[126] Frische T, Mebes KH, Filser J. Assessing the bioavailability of contaminants in soils: a review on a recent concepts Berlin. Research Report 2003;201 64214.

[127] Hammesfahr U, Kotzerke A, Lamshft M, Wilke BM, Kandeler E, Thiele-Bruhn S. Effects of sulphadiazine-contaminated fresh and stored manure on a soil microbial community, European Journal of Soil Biology 2011;47 61-68. 
